\title{
The Curious Case of the Unrecognized turba of amir Jirbāsh Qāshiq: New Dating and Attribution
}

\author{
Hani Hamza \\ Independent Scholar, PhD Cairo University, MA American University in Cairo \\ hamzahani@icloud.com
}

\begin{abstract}
The borderlines between the sacred and profane, and the living and the dead, are blurred in the Mamluk Northern Cemetery of Cairo like in no other place in Egypt. Sacred burial domes, prayer chapels, mosques, șüfi khanqās, and zawīyyas stood side by side with profane residential quarters, kitchens, latrines, stables, kutābs, and sabīls scattered around a haūsh enclosed by a wall. The Northern Cemetery was dotted with over a hundred of such Mamluk turba complexes. Many perished, but thirty-six survived.

The majority of surviving turbas are identified with certainty, but a few have controversial attributions or doubtful dating. One surviving turba stands out as not being recognized at all, let alone given an attribution or date. This is the peculiar case of the turba of Jirbāsh Qāshiq (d. 861/1456), standing between the complexes of Īnāl and of Qurqumās at the edge of the Northern Cemetery.

The plan of İnāl's complex $\left(855^{-60} / 145^{-56}\right)$ has a peculiar square area protruding uncomfortably to the west, now in semi ruins. It was identified empirically by the Comité in 1919 as courtyard C of the complex of Innāl. None of the later studies challenged this attribution. This paper will discuss the vague attributions of three turbas in the area in general, and as a case study challenges the Comité's attribution of the haush C as part of Ināl's complex; it proposes that it is a separate turba for Jirbāsh Qāshiq. This conclusion is reached through reading of several waqf manuscripts, comparisons with other monuments of the same genre and era, biographical dictionaries, and chronicles. A plan and a three-dimensional re-construction of the turba are drawn as well.
\end{abstract}

\section{Keywords}

attribution - Comité - Mamluks - Șaḥarā’ - turba - Waqfìyya

The existence and approximate site of the turba of Jirbāsh Qāshiq outside of Cairo (the Northern Cemetery) is known to the bulk of Mamluk scholars from the waqfyyas of Sulțān Înāl (r. 857-65/1453-6o) and amìr Qurqumās (d. 916/1510). The turba is mentioned in several sources, as will be shown in the literature reviews below. However, the consensus of modern scholarship is that it perished or disappeared under a newer structure like scores of other monuments in the area. I am arguing here that it did not perish or disappear, but that it still exists in semi-ruin, erroneously identified as a court belonging to the complex of Sulțān al-Ashraf Īnāl (Index, 158, 855-6o/1451-5). ${ }^{1}$

I will start with a survey of literature and excavation works related to the complexes of Īnāl and the adjacent Qurqumās, as the turba of Jirbāsh Qāshiq is located between 
them. After that I will discuss the meaning of turba, the area which is best known as Șaharā̄ al-Mamālīk during the Mamluk period, and the ambiguity of the names and dates of several of its surviving Mamluk monuments, before proceeding to the main argument. The methodology adopts a multidisciplinary approach: archival, by scrutinizing the waqfiyya documents; literary, by using contemporary historical narratives; and architectural, through a survey of the site that compares its layout with the layout of surviving neighboring monuments and those that have disappeared (through their respective surviving waqfyyas), in order to reconstruct a plan and $3 \mathrm{D}$ model of the turba of Jirbāsh Qāshiq.

The complexes of al-Ashraf Īnāl, and Qurqumās and the surrounding area were subjected to comprehensive studies and restoration works by the Comité du Conservation des Monuments de l'Art Arabe (Comité for short) since its establishment in 1882, and again by a Polish-Egyptian Project that started in 1972; both will be discussed in detail below. In the literary domain both complexes were adequately studied, either individually or as part of the Cairo cemeteries, in art history books and academic dissertations.

Stanley Lane-Poole mentioned the complex of Īnāl as early as $1886,{ }^{2}$ and described the mosques of the area, which he called the "Tombs of the Kalifs," in another contribution. ${ }^{3}$ Martin Briggs visited the area that he calls the "Eastern Cemetery," including the complexes of Īnāl and Qurqumās, in 1919 and described it as being in a "ruinous condition" with an "interior in a lamentable state." K.A.C. Creswell described both complexes, as well in 1919. ${ }^{5}$ None of those early references described or mentioned the complexes in enough detail to include the adjacent turba of Jirbāsh Qāshiq, apart from a few that we will deal with here.

Almost all the literature dealing with Mamluk architecture or the Cairo cemeteries also covers the two complexes. There are too many to enumerate here; however, there is no monograph on either complex. There are three academic dissertations on the subject: Mustafa Naguib's PhD dissertation on the complex of Qurqumās, ${ }^{6}$ Sami Hasan's $\mathrm{PhD}$ dissertation on Īnāl's buildings, ${ }^{7}$ and Joyce Tovell's MA dissertation on the complex of İnāl. ${ }^{8}$ All dissertations mention the turba of Jirbāsh Qāshiq and maintain that it perished at an unknown time, as we point out throughout this article.

As for the history of the cemeteries of Cairo and their topography, there are the studies of Yusuf Ragib, mainly focusing on the Fatimid period; of Muhammad Hamza and the present author, focusing on the Mamluk era; and of Galila El Kadi, covering the modern period. I will refer to these relevant studies throughout this article and in the bibliography. Christopher Taylor wrote a pioneering monograph on the tomb visitation or ziyāra, the related guide books, and its rituals in medieval Cairo. ${ }^{9}$ Ohtoshi Tetsuya wrote about socio-economic life in the Cairo cemeteries, ${ }^{10}$ and compiled a comprehensive survey of the literature on the cemeteries of Cairo. ${ }^{11}$

\section{Meanings of turba}

Turba comes from the word turāb, meaning soil, dust, or the nature of the upper layer of the earth. ${ }^{12}$ According to Ibn Manzūr (d. $\left.711 / 1311\right)$, the turba of a human being is his rims (turbat al-insān rimsih) and the turba of the earth is its upper layer (wa turbat al-ard $z \bar{a}$ hirha $).{ }^{13} \mathrm{He}$ defines al-rims as the grave (al-qabr),${ }^{14}$ which means that he confines the meaning to the grave only, without any structure or mark that could be associated with 
it. In the context of funerary architecture, the simplest, most basic meaning in modern Arabic is qabr, ${ }^{15}$ grave or tomb: an underground burial chamber marked by a tombstone (shāhid) or sarcophagus (tābùt), or unmarked according to the Arabic tradition.

Mamluk waqfiyyas use the term fasqiyya to denote underground burial chambers, among other meanings. ${ }^{16}$ Dozy singles out turba for the mausoleum or a mosque constructed over a qabr (tomb). ${ }^{17}$ A turba in the time of the Mamluks was not limited to a burial place or grave, but became an establishment, serving sacred and secular tasks, burial being only one of them. The turba enclosure could also include a mosque, madrasa, khanqāh, sabïl, minaret, residential quarters, stable, kitchen, etc. ${ }^{18}$

The borderline between the sacred and profane, the living and the dead, is blurred in Șaharā' al-Mamālīk, the Mamluk Northern Cemetery of Cairo, like in no other place in Egypt. Sacred structures such as domed mausoleums, prayer chapels, mosques, sū $f \grave{\imath}$ khanqāhs, and zawiyyas stood side by side with profane residential quarters, kitchens, latrines, stables, kutābs, and sabïls scattered around a haūsh enclosed by a wall. Scores of such assemblies dotted the alleys of the Șaharā', forming one of the most popular cemeteries of Medieval Cairo, ${ }^{19}$ though not the most sacrosanct, as none of the $\mathrm{Ahl}$ al-Bayt (the direct descendants of the Prophet) or any other major Muslim saintly characters are buried in the area.

At least 106 Mamluk structures, mainly turba complexes built from the beginning of the eighth/fourteenth century to the first quarter of the tenth/sixteenth century onward, have been identified in the Șaharā'. ${ }^{20}$ Many have perished, but thirty-six have survived. The majority of these turbas have been identified conclusively, but the attributions and dating of a few of them is doubtful. One surviving turba stands out among them, as it is considered to be part of a different complex with a wrong attribution and date. This is the peculiar case of the turba of Jirbāsh Qāshiq (d. 861/1456), located between the complexes of Īnāl and of Qurqumās at the edge of the Șaharāa, and the subject of this article.

Șaharā' al-Mamālìk is one of the names of the area, ${ }^{21}$ extending outside the eastern walls of Cairo up to the Muqațam hill in the east; its southern limit is the slope of the cemetery of Bāb al-Wazīr, north-east of the citadel. The northern limit is more ambiguous and extends up to Raydāniyya (north of Cairo) (Fig. 1). The history of the area reflects to a great extent the history of the Mamluk sultanate; it was used for military parades, as a hippodrome for the practice of war games, and as a horse race track by al-Z̄āhir Baybars (r. 658-76/126o-77) and his successors, beginning in 662/1265 during the early Bahri Mamluk period. ${ }^{22}$ With the relaxation of military zeal caused by the final expulsion of the Crusaders from the Muslim East in 69o/1291, and the waning of the Mongol threat during the long third reign of al-Nāșir Muhammad (709-41/1310-41), the military nature of the area faded. Instead, it was used by al-Nāșir Muhammad as an entertainment park for banquets, hunting sports, polo games, and horse racing with his highly prized herd of Arabian horses..$^{23}$ In short, it became an arena for the worldly pleasures of an affluent, relaxed sultan.

A third and final phase in the development of the Șaharā' took place around 711/1311-2 when the amìr, Shams al-Dīn Qarāsunqur al-Manșūrī (d. 728/1328), ${ }^{24}$ built a mausoleum, a mosque, and a sabil for himself at the northern side of the Șaharầ. ${ }^{25}$ Amìrs, 'ulam $\vec{a}$, Sufis, religious figures, merchants, and other dignitaries followed suit and built edifices as their final resting place. No sultan, however, sponsored any building during the entire Bahrī period (648-784/126o-1382). The first sultanic foundation at the Șaharā was the khanqāh of Faraj b. Barqūq (Index 149, 803-13/140o-11). Several other sultans followed his example, building impressive turba complexes, ${ }^{26}$ all but one of which still exist. 


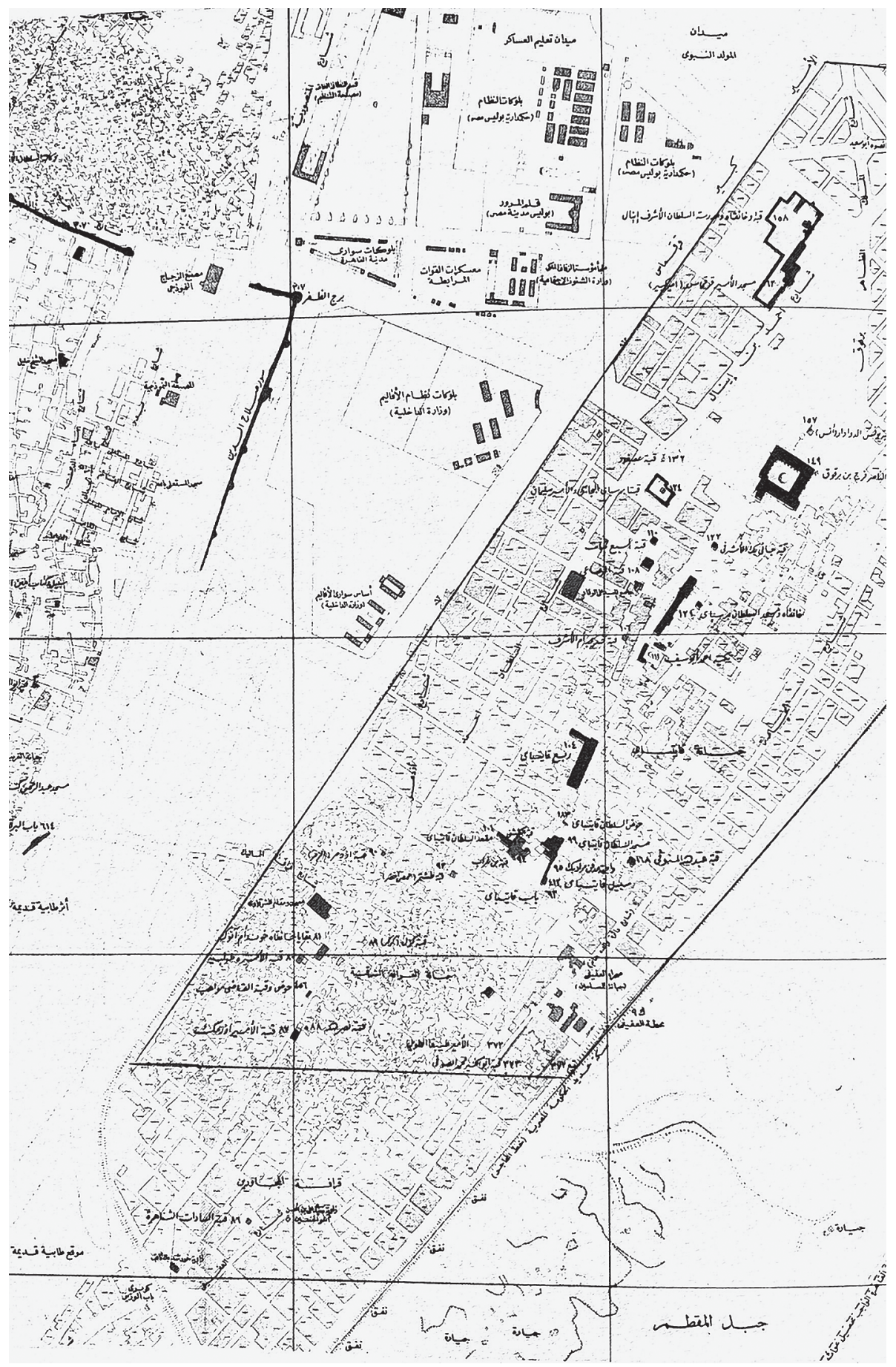

Following the phases of development of the Șaharä is beyond the scope of this study however; ${ }^{27}$ we will only focus on the existing Mamluk-era monuments with disputed dating and/or attribution, and on the complex of Innāl vs. the Comité du Conservation des Monuments de l'Art Arabe (Comité for short).

The only four existing monuments from the Bahrī period (648-784/126o-1382) are all properly attributed and dated. There are, however, six monuments in various conditions of semi-ruin at the Șaharāà that have scholars disagree on their dating and attributions,
FIGURE 1

Șaharāā al-Mamālīk (The Northern Cemetery of Cairo) SURVEY DEPARTMENT OF EGYPT 
due to the absence of foundation inscriptions or clear references in contemporary sources. These monuments are registered in the Index issued by the Survey of Egypt under their most popular name, which is not necessarily the most correct one. They are all from the Burjī period (784-922/1382-1517).

The dating and identity of the founder of Macbad or Qubat al-Rifāi (Index 108) ${ }^{28}$ is controversial, though not the name, as it belonged to the Rifấiyya order according to an inscription on the drum of the dome. ${ }^{29}$ The Comité and the Index date it to the beginning of the tenth/sixteenth century, the period of the Burjī Mamluks, without any validation; Qāsim and Behrens-Abouseif attribute its foundation to al-Ashraf Barsbāy in $837 / 1433$, based on his waqfyya with the same date. ${ }^{30}$ It seems that Yashbik min Mahdī (d. $885 / 1480$ ) renovated the dome in $884 / 1479$, according to a waqfiyya mentioned by Qāsim, ${ }^{31}$ without the citation and inscription band mentioned by Behrens-Abouseif that have now disappeared. ${ }^{32}$

An anonymous mausoleum still stands near the complex of al-Ashraf Barsbāy, called Qubat al-Saba Banāt (Dome of the Seven Girls) by the Index (no. 110) and dated to the middle of the ninth/fifteenth century, based on the designation of the Comité, ${ }^{33}$ without convincing evidence, and no doubt based on the popular name. Attribution varies widely in existing literature. Creswell, on stylistic grounds, dated it to c. $845 / 145$ o, but he did not speculate about the name of the founder. ${ }^{34}$ Qāsim was more daring, as usual; he dated it to 886/1481 and attributed it to Amīr Qajmās al-Īshāqī (d. 892/1486), again without corroboration. ${ }^{35}$ This quba cannot be the turba built by Qajmās, as the latter is located near the turba of Qānim al-Tājir (d. 871/1466), and the complex of İnāl, ${ }^{36}$ while this existing quba is far away from both. ${ }^{37}$ Meinecke assumed it to be the mausoleum of Amīr Yashbak al-Sudūnī (d. 849/1445), based on contemporary sources that mention the burial of this amìr at his unfinished mausoleum near the complex of Barsbāy at the Saharāà ${ }^{38}$

An anepigraphic dome that also still stands, opposite the complex of Barsbayy, is popularly known as Khadīja Ūm al-Ashraf (Index 106 c. 835-45/1430-40), based on the Comité's designation. ${ }^{39}$ Creswell identifies this Khadīja as Ūm al-Ashraf Barsbāy, based on popular tradition, and perhaps because its proximity to the complex of Barsbāy. He dates it to c. $835^{-45} / 1430-40$, based on the rare decoration of the outer surface of its dome, which appeared on only one other example in Cairo from that era. ${ }^{40}$ Qāsim almost agrees with Creswell on the date of foundation - 846/1442 - but attributes it to another Khadijja, the daughter of al-Ashraf Karīm al-Dīn b. al-Jay'ān. ${ }^{41}$ Both attributions seem to be incorrect, as al-Ashraf Barsbāy's biography is well documented in the sources, and does not mention his mother; also, the famous Jay'anns are known to have a family mausoleum in another place, also in the Șaharẳ. ${ }^{42}$

The youngest monument in Șaharā' al-Mamālīk is Qubat 'Așfūr (Index 132), dated c. 912/1506 based on the designation of the Comité. ${ }^{43}$ Creswell also dates it to after 913/1506, perhaps even to after the Ottoman conquest of $923 / 1517$, as he considers the decoration of the outer surface of the dome to be an inferior imitation of the nearby dome of the mausoleum of Qurqumās (Index 162, 911-3/1506-7). He also notes that the cartouches on the drum of the dome contain the Muslim profession of faith rather than the usual name of a sultan or a founder. ${ }^{44}$ Again, Qāsim assertively dates it to 806/1404, as the popular name of the quba, 'Āṣfūr, is similar to that of a calligrapher and clerk from the times of the reign of al-Nāșir Faraj (801-8/1398-1405 and 808-15/1405-12) whose sobriquet was ibn 'Aṣfūr, and who died in 808/1406; however, Qāsim provides no further evidence. ${ }^{45}$

The last four controversial examples are detached single domes - or that is what they seem now - but there are two more examples of a foundation containing sub-units scattered around an inner court, and surrounded by a wall. The first is the so-called Tikiyya of Aḥmad Abū Sayf (Index 111), ${ }^{46}$ dated ninth-fifteenth century, based on the designation 
of the Comité. ${ }^{47}$ According to the files of the Supreme Council for Antiquities (SCA), its founder is Aḥmad b. Muhammad b. Yūsuf, also known as Ibn Sayf who lived and died in Bailbais. ${ }^{48}$ The file does not give any other clues, especially none as to why a Mamluk foundation is designated tikiyya, an Ottoman term for șüfi hostels. It does also not explain the uncommon sobriquet of Abū Sayf. ${ }^{49}$ Qāsim empirically dates it to 748/1348, and attributes it to Üljāì Bugha al-Muzafarīi. ${ }^{50}$ Al-Muzafarī, however, is known to have had a khanqāh in another area in the Șaharā', which cast doubts on this attribution. ${ }^{51}$

Answers to the above questions can only be found through the methodical examination of the monument. A case in point is the second example referred to above: Qubat Azdamur (al-Zumur) (Index 9o), dated to the end of the ninth/fifteenth century by the Comité and the Index..$^{52}$ Creswell, from his photographic archives at the American University in Cairo, attributed it to Azdamur Timsāh and dated it to 9oo/1495, the year he died. ${ }^{53}$ No attempt was made to verify the name Azdamur, which is a very common name among the Mamluks, or to narrow the date range proposed by the Comité. Qāsim dated it to 899/1493, based on an inscription he read on the tombstone of a lady buried in the court of the monument with that date, and empirically attributed it to Azdamur min Bilbāy (Timsāh $)^{54}$ The present author carried out a thorough multidisciplinary study of the monument through an architectural comparative analysis, the use of contemporary literary sources, an analysis of the decorative scheme, a site survey, and Creswell's photo archives, and concluded that the founder was Azdamur al-Ībrāhīmī al-Zāainiri al-Ṭawīl, and that the monument was founded in 855/149o, the date of his sudden execution. ${ }^{55}$

\section{The Polish-Egyptian Restoration Project at the Complexes of al-Ashraf Īnāl and Qurqumās}

The restoration project was started in 1972 by a Polish-Egyptian group, ${ }^{56}$ and continued well into 1992, with the aim of restoring the complex of Qurqumās, but the work was extended to include the adjacent complex of Ināl. The group activities were not limited to construction work only, but included historical studies, measurements and documentation of the buildings, comparative studies of surrounding monuments, anthropological studies of bone remains found at the sites, and excavations of the area around the site that revealed interesting information on the use of the area prior to the construction of the complexes. Most of the restoration works took place at the complex of Qurqumās, on the façades and the interior, including the water and sewage systems, which brought the monument back in good shape. Ināl's complex, on the other hand, received less attention due to a lack of funds, and the work was limited to the clearing of the site and the removal of debris. ${ }^{57}$

The Polish-Egyptian group adopted a methodology different from the the ones that formed the basis of previous art historical publications, as theirs focused on the art of the building, construction techniques, and the materials used. They examined and restored the hydro-sanitary installations and followed up with the erection sequence of the individual parts of the complex of Qurqumās. They also examined the hitherto uncovered crypt and underground galleries. ${ }^{58}$ An excerpt from the waqfyya of Qurqumās that describes the complex was translated into English and published. ${ }^{59}$

The layout and plans of the two complexes drawn by the Polish-Egyptian group were identical to those of the Comité. Again, they assumed that the turba of Jirbāsh Qāshiq was on the western side of the complex of Ināl, next to the "domestic courtyard," referring to Court $C$ of the standard plan of the complex of Ināl, and concluded that it did not exist anymore. ${ }^{60}$ 
The Comité had shown a keen interest in this monument located at the Șaharā', from its inception in 1882. In the first issue of the Bulletin of the Comité, covering the activities of the years 1882-83, and published in 1892, this monument is mentioned in the eighth report of the Technical Committee (Deuxième Commission). According to the author of this report, the Department (Ministry) of War used the monument for the storage of gunpowder, before responsibilities were transferred to the Department of Waqf (pious endowment) who was the actual owner of the property. The abandoned building was in complete ruin; the upper galleries of the minaret were lost, the walls had cracked, the lintels had collapsed, the marble floors and mosaics were gone. Although they admitted that the complete restoration of the structure was very challenging, the Commission nevertheless recommended urgent repair and consolidation of the monument, as it is a rare example of Arab architecture from the ninth/fifteenth century. ${ }^{61}$ The Comités effort to save the complex of Īnāl continued for a long time, as we will briefly cover here.

The first problem that the Comité had to face, was that the building was in the custody of a certain Muhammad Effendi Amin as nāzir (superintendent) of the waqf, the only person authorized to make arrangements for the guarding and repair of the property. ${ }^{62}$ It took the Comité almost ten years to allocate the then substantial sum of forty Egyptian pounds for repair works to be executed by the näzir through the waqf administration, but the latter was then unable to get in touch with the nāzir, who had disappeared. Consequently, the Comité and the waqf administration agreed to sue the nāzir and force him to cede his authority over the complex of İnāl. ${ }^{63}$ The same desire for legal action by the Comité for removal of the nāzir was expressed in $1895 .{ }^{64}$ Finally, the näzir re-appeared and started the intended 30-day repair of the property on January 21, 1895, according to the specifications of the Comité, a task he obviously did not finish. ${ }^{65}$ The Waqf Department was finally able to oust the negligent guardian and gained control over the property in August 1895. The Comité requested the guardianship of the royal monument, commissioned a report for its preservation, and allocated funds to prevent intruders from damaging the property further. ${ }^{66}$ However, the Comité only recommended the clean-up of the façades and the outer parts of the monument, as they considered the internal parts to be worthless. ${ }^{67}$

In 1899 the custody of the Inaal complex was transferred again from the Waqf

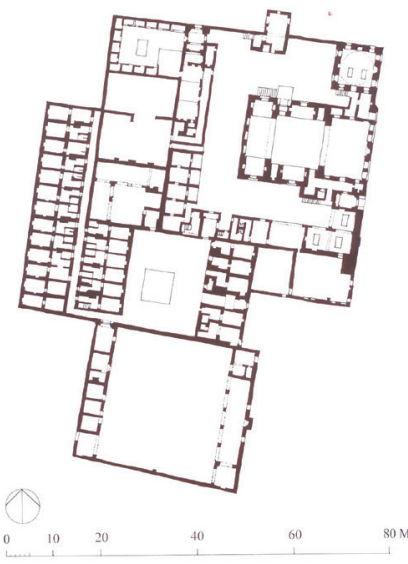

FIGURE 2

Plan of the complex of Īnāl by Patricolo

AFTER THE COMITÉ (1922). FASCICULE 32, EXERCICE 1915-1919, PP. 146. (RE-DRAWN)
Department to a new nāzra (female superintendent) who was responsible for the management and preservation of the property and forbidden by the Comité to make any changes to it without the prior approval of the Comité ${ }^{68}$ However, the new custodian neglected to have the complex properly guarded, and it was pillaged by marauders, with considerable damage to this important monument. Consequently, the Comité requested that the custody of the monument be returned to the waqf administration. ${ }^{69}$ This was only possible through a court ruling, ${ }^{70}$ which was eventually obtained on 24 March 1906, at which time the property was finally handed over to the waqf administration. ${ }^{71}$ It took the Comité almost ten more years to visit the property again, assess the damage caused by the abandonment of the monument, and document some parts of it, especially the minba $\bar{r} .^{72}$

The pinnacle of the Comité's efforts to salvage the complex of Innāl is a report published in $1922^{73}$ by Achille Patricolo, ${ }^{74}$ in which he reviews the efforts of the Comité that eventually led to the clearing of the rubble and debris that hid the site's buildings. An older plan of the site by the Austrian architect Julius Franz Pasha (d. 1915), a former director of the Technical Bureau of the Waqf Administration, was replaced by a new plan drawn by Patricolo (Fig. 2). ${ }^{75}$ This latter plan remains to this day the official version used by most subsequent studies of the complex. 


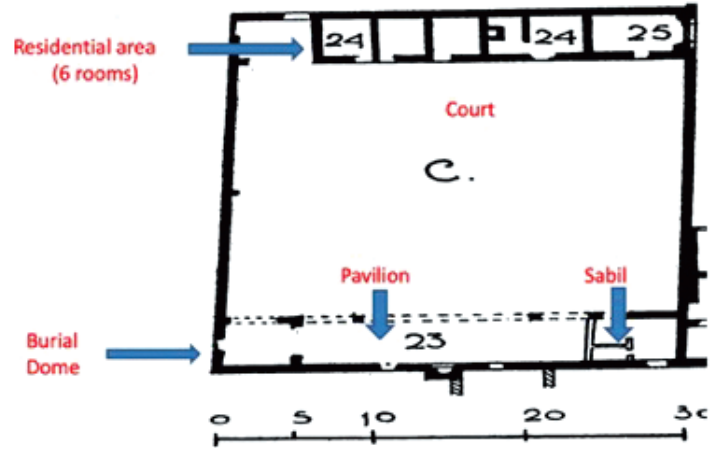

The plan basically divided the complex into three enclosures (A, B, and C), each consisting of a central open court with architectural units surrounding it, as identified by the Comité. Enclosure A had a madrasa, a domed mausoleum, residential area, sabül, and latrines. Enclosure B had a khanqāh, water cistern, minaret, residential area, and other features.

Enclosure C, the subject of this study, was called hawsh C (Fig. 3) by the Comité. It was located to the south of the khanqāh. It consisted of a large rectangular enclosure with a portico/pavilion with a mihrab (23) at its eastern side, a residential area consisting of six rooms (24) at the western side, and a vestibule with a portal decorated with a blazon, which was not described in the report. The author of the report wondered why such a medium-sized portal with neat decoration would be hidden behind the rooms of the khanqāh, and concluded that the portal was built before the expansion of the complex ordered by Īnāl. ${ }^{76}$

\section{Court C: Description and Reconstruction}

A rectangular enclosure $31 \mathrm{~m} \times 36 \mathrm{~m}$ is now surrounded by the complex of Īnāl to the north, the complex of Qurqumās to the east and south, and an empty tract to the west. Several units in a state of semi-ruin can be identified within an enclosure around an open court (Fig. 4). A monumental arched stone entrance at the north-western corner

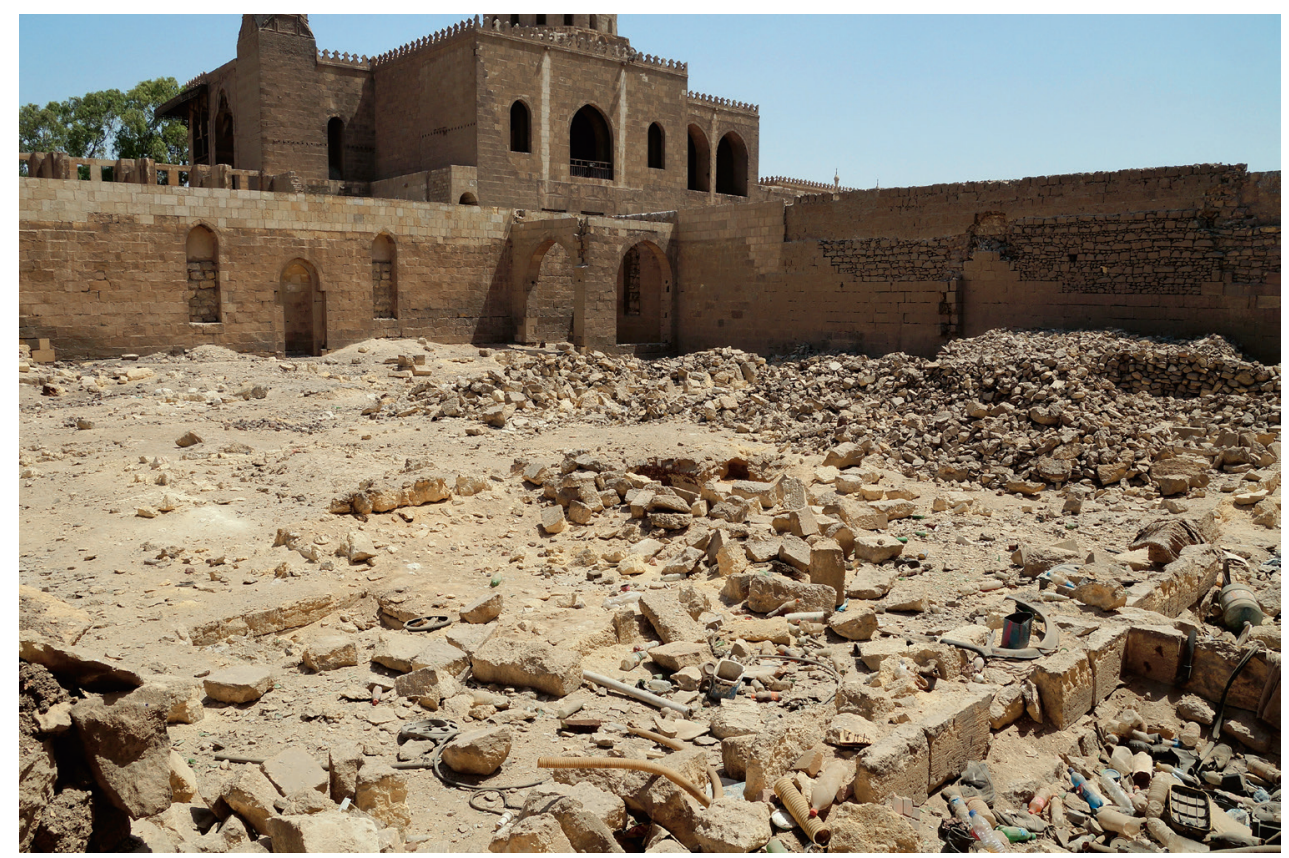

FIGURE 3

Court $\mathrm{C}$ by the Comité
FIGURE 4 Inner court (hawūsh) BY THE AUTHOR 


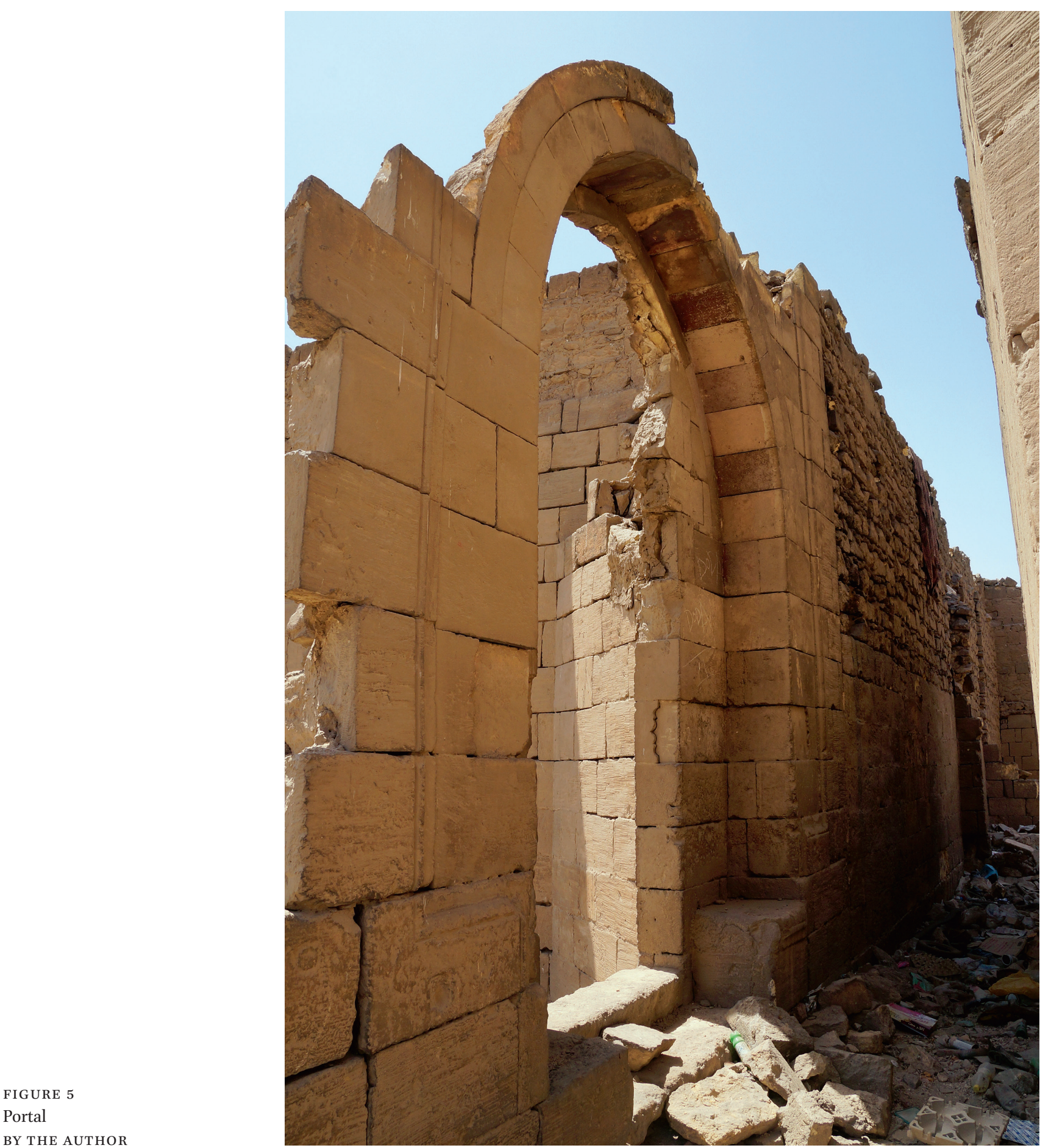

of the enclosure leads to the court through a vestibule (dirkāh), flanked by two benches and an erased inscription band (Fig. 5). The remains of the residential area, divided into six rooms, are behind the vestibule (Fig. 6) to the west of the inner court, an area covered by dust and debris. The eastern side of the court (qibla) is divided into three parts. In its northern corner is a sabil (Fig. 7), which is elevated and has a square plan containing a cistern inside. Next to the sabill, in the middle part, are the remains of an arcaded pavilion maqșüra with a central niche flanked by two recesses (Fig. 8). The southern corner is a square room with two arched entrances that has lost its ceiling (Fig. 9), which seems to have been a dome for a burial. 

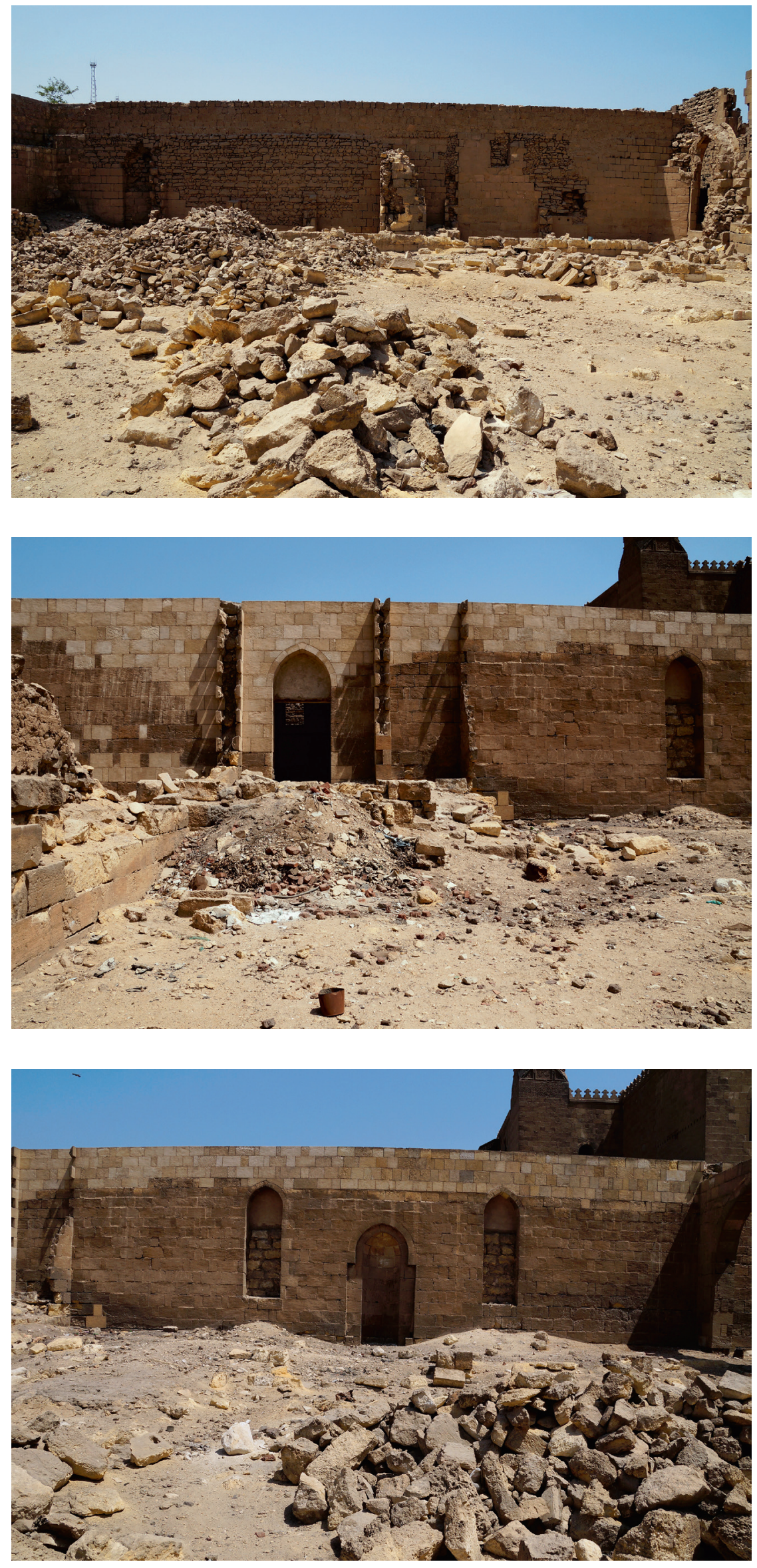

FIGURE 6

Residential area BY THE AUTHOR

FIGURE 7

Sabïl

BY THE AUTHOR
FIGURE 8

Maqșūra

BY THE AUTHOR 
FIGURE 9 Burial chamber BY THE AUTHOR

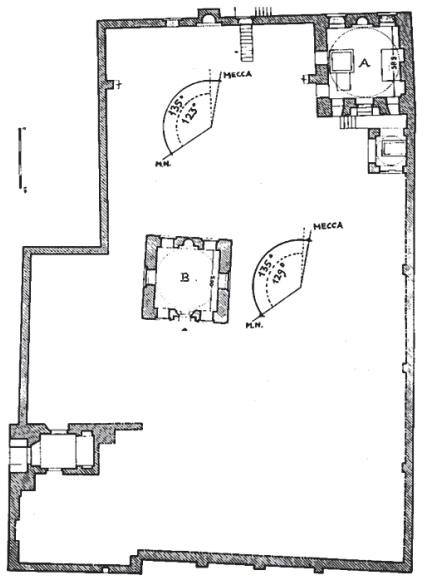

FIGURE 10

Plan of the turba of Barsbāy al-Bajāsī

AFTER KeSSler (COURTESy OF THE RARE BOOKS AND SPECIAL COLLECTIONS LIBRARY OF THE AUC)

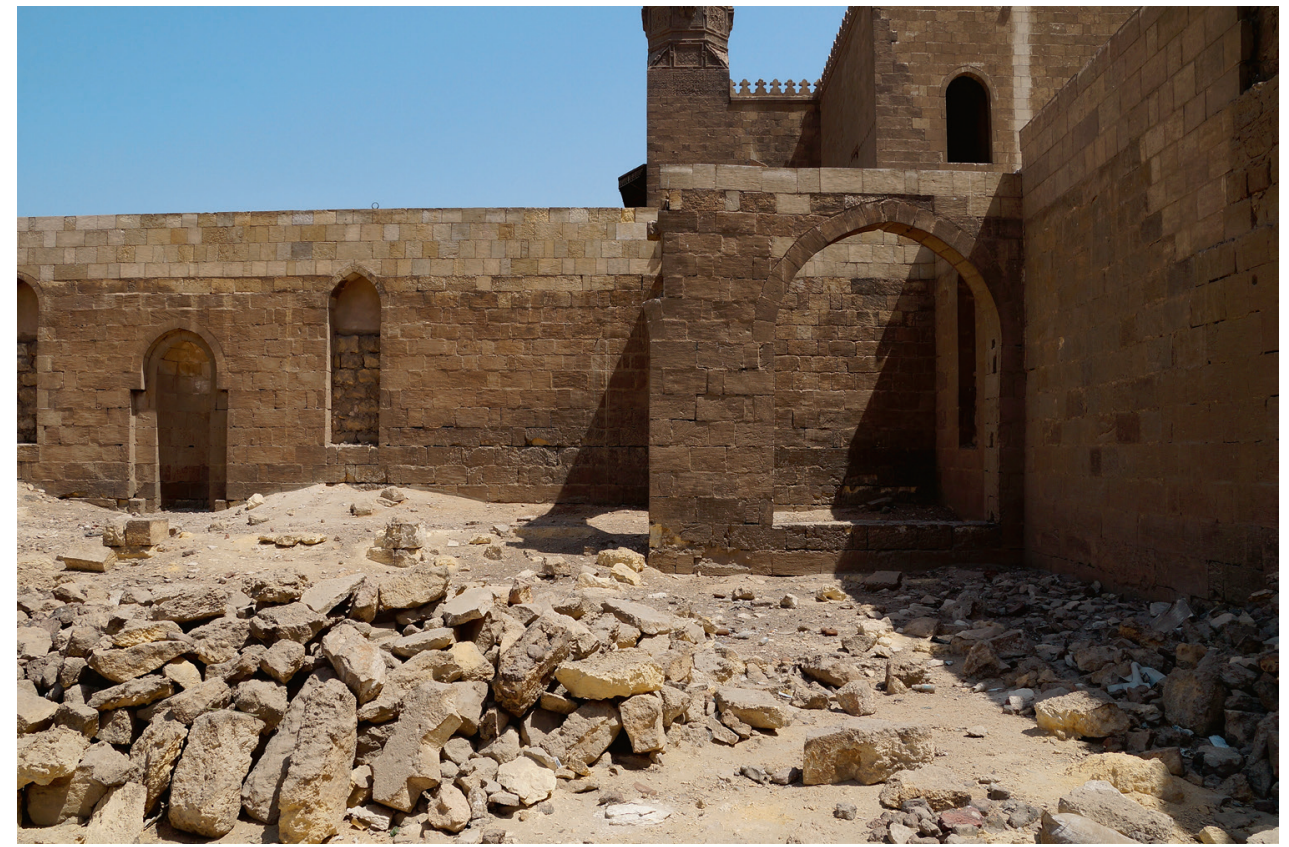

From the previous description we can conclude that this area qualifies as a turba, with all its elements similar to other foundations in the area. ${ }^{77}$ Based on an actual site survey, a plan of the turba was drawn by the author (Fig. 12). A three-dimensional reconstruction of the building can be seen in Fig. 13, showing its various units: the entrance, vestibule, residential quarters, sabīl, pavilion, burial dome, and inner court.

\section{Why Is This Court Not Part of the Īnāl Complex?}

It does not take a wild imagination to see that this court is not part of the complex of Ināl as the Comité proposed. Many reasons lead us to think it is a separate entity on its own. The court protrudes uncomfortably outside the plan of Ināl, so that it is not a logical part of it. The waqfiyya of Ināl does not mention this court, but the waqfiyya of Qurqumās mentions a small alley, zuqāq lațīf, at the northern border, ${ }^{78}$ which separates it from the complex of Īnāl and from a turba known by the name of Jirbāsh Qāshiq. ${ }^{79}$ This small alley still stands today, separating the two complexes and the so-called Court C.

Another obvious clue is the monumental stone entrance to Court $\mathrm{C}$ that is hidden by the southern part of the khanqāh of Ināl. Why would someone build a beautiful entrance to be hidden by another of his own making? Unless, of course, the entrance was older and the khanqāh came afterwards as a separate establishment. ${ }^{80}$

No less anomalous are the redundant court's units: the residential area, sabül, belvedere, burial dome, and monumental entrance that exist already at the Īnāl complex on a larger scale. Such illogical duplication of units can only be explained by assuming that the court was an older, separate entity.

Patricolo, Chief Engineer of the Comite in 1922, questioned the function of this enclosure, and dismissed the assumption that it could be the zawiyya ordered by Ināl and mentioned by ibn Iyāss, ${ }^{81}$ as other areas of the complex answer this description equally well, but he did not come to any conclusion. He also assumed the presence of the remains of the three turbas of Ibn Fadil Allah, ${ }^{82}$ al-Zaynī 'Abd al-Bāsit (d. Shawwāl $854 / 1450),{ }^{83}$ and Jirbāsh under debris to the north of the complex of Qurqumās. ${ }^{84} \mathrm{He}$ 


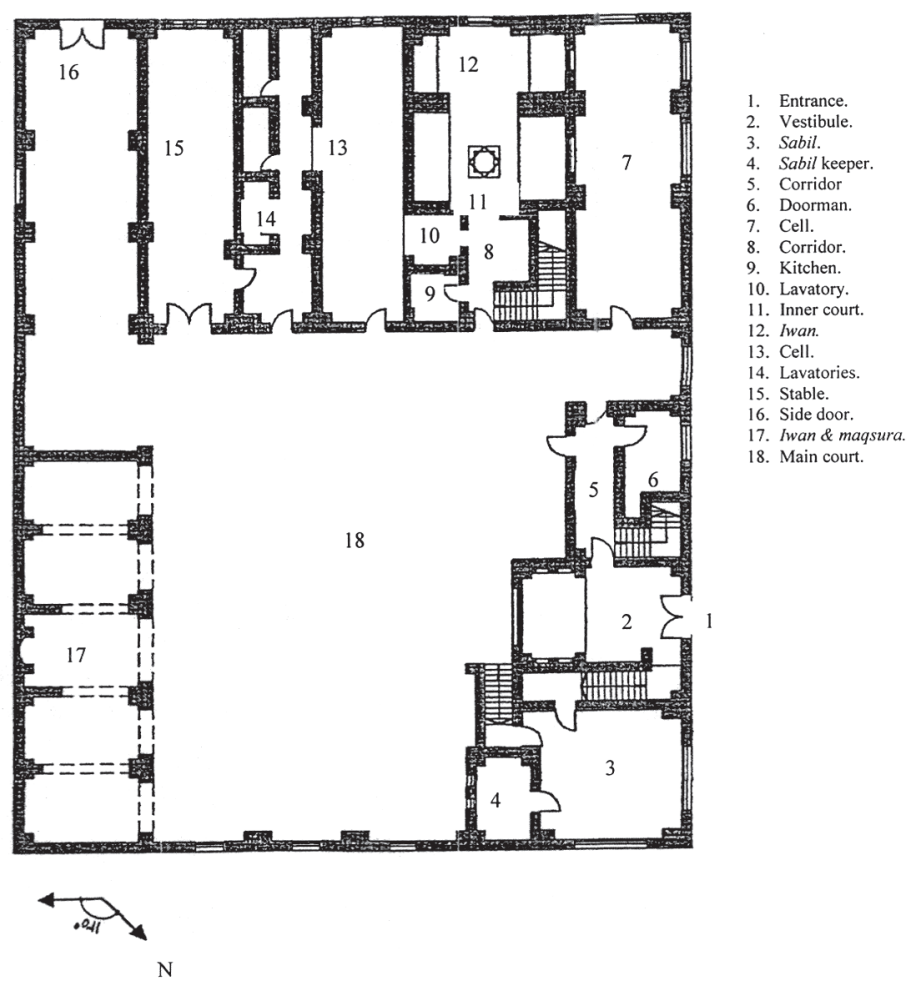

FIGURE 11

Reconstruction of the plan of turba of Abū al-Mahāāsn b. Taghrībirdī BY THE AUTHOR
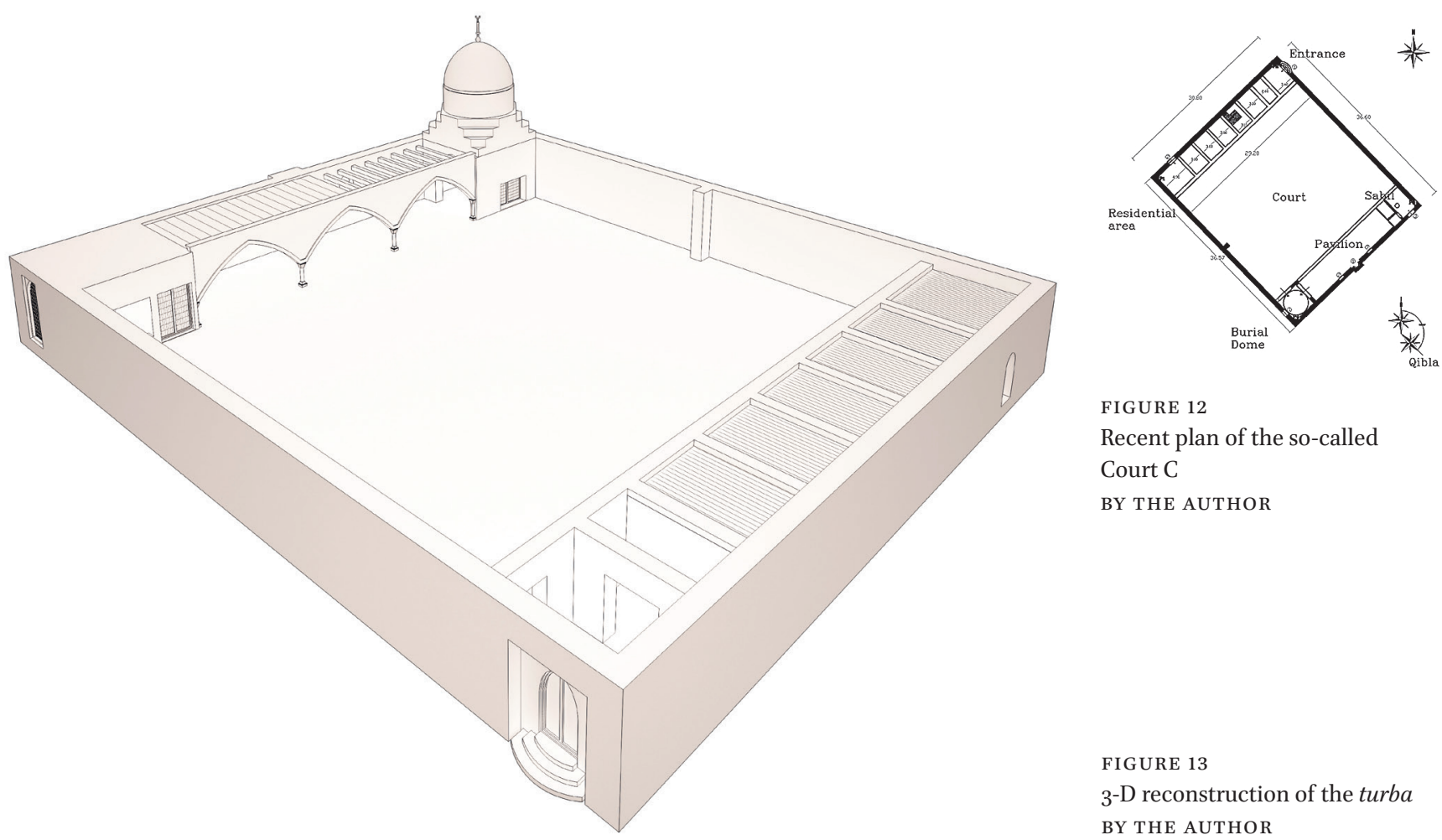

FIGURE 12

Recent plan of the so-called Court C

BY THE AUTHOR

FIGURE 13

3-D reconstruction of the turba BY THE AUTHOR 
based his conclusion on the relevant part of the waqfyya of Qurqumās, which he translated into French. However, he did not conduct any further investigation or speculate on a connection between Court $\mathrm{C}$ and those missing edifices. This part of the waqfiyya, which will be discussed in more detail, is a key point in the attribution.

The German archaeologist Michael Meineke suggested in 1972 that this enclosure is not part of the Īnāl complex, and summarily attributed it to Kūkāī al-Silāḥdār (d. 749/1349). ${ }^{85}$ He jumped to this conclusion based on the presence of a loose stone rank (blazon) of a silāhdār with a sword that he found in the semi-ruined enclosure, without giving any further evidence. ${ }^{86}$ This attribution and the stone blazon will be discussed later in more detail.

The opening of the waqfiyya of Innal mentions ${ }^{87}$ that the madrasa is adjacent to the turba of al-Sayfî Jirbāsh al-Karīmī, ${ }^{88}$ which means that the turba of Jirbāsh preceded the madrasa and that it was a landmark of the area, used as a reference point for defining the location of the madrasa of Īnāl. At its end, the waqfoyya states that at the western border (meaning the topographical south, as explained above) lie the turbas of amir Jirbāsh and of the late al-Zaynī Abd al-Bāsiț.

More crucial for our argument here is the waqfiyya of amìr kabìr Qurqumās min Wallī al-Dīn (d. 916/1510) for his complex in the Șaharā'89 (Index 162, 911-2/1506-7). It describes the four borders of the plot - the eastern (qiblī) border being the main road and identifies the windows of the various parts of the entity and the doors that overlook the road. The western border ( $b a$ harī) overlooks the turba of Ibn Fadal Allah, two alleyways $(z u q \bar{a} q)$, another road, and the turba of al-Qāọī Abd al-Bāsiṭ mentioned earlier. The southern border ('western' in the waqfiyya) overlooks another road and has one blocked door that leads to the main court of the Qurqumās complex. ${ }^{90}$

The northern border ('eastern' according to the waqfiyya) and the one most important to us is defined as follows: ${ }^{91}$

... The eastern border ends ${ }^{92}$ at the road [main road] and it includes the portal of the mentioned madrasa, the stairs and the staircase landing $[\text { basta }]^{93}$ ' which contains marble orbs [ramāmin, singular rumāna $]^{94}$ and the second window ' of the two windows of the sabil ' and part of it (overlooks) a small (latîf) cul-de-sac $(z u q \bar{a} q)$ that separates that [the madrasa of Qurqumās] and ' the turba of al-Ahraf Ināl referred to earlier and this [cul-de-sac] contains a door ' $[\text { bāb macălim }]^{95}$ to a flour mill ${ }^{96}$ and a door to a passageway $[\text { maja } z]^{97}$ that had the doors ' to the residential units [arwiqa, singular riwāq $]^{98}$ mentioned earlier, then the turba known for Jirbāsh `Qāshūq [sic]...99

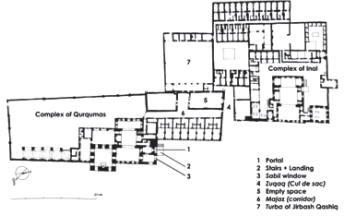

FIGURE 14

Combined plan of the complexes of Īnāl and Qurqumās AFTER THE COMITÉ (1922). FASCICULE 32, EXERCICE 1915-1919, PP. 146 AND 166
In other words, this border, according to the waqfyya, was along the main road, which included the portal (1), the staircase that led to a landing (basta) with a balustrade decorated by orbs (both disappeared now) (2), a sabil window (3), and a cul-de-sac (zuqāq) that separated the complex of Qurqumās from that of Īnāl (4). This cul-de-sac had two doors: one to a space intended for a flourmill that was never built (5), and the second to a passageway (majāz) with (eight $)^{100}$ doors, each leading to a residential unit (riwāq) (6). Finally, the cul-de-sac ends at the turba of Jirbāsh Qāshiq (7). This arrangement is shown in Fig. 14 that combines plans of both complexes.

Luckily, this cul-de-sac $(z u q \bar{q} q)$ that separates the Īnāl and Qurqumās complexes still exists today, with all the units described by the waqfiyya (Fig. 15), including the empty room intended for the flourmill (Fig. 16). The so-called Court C stands at its end 

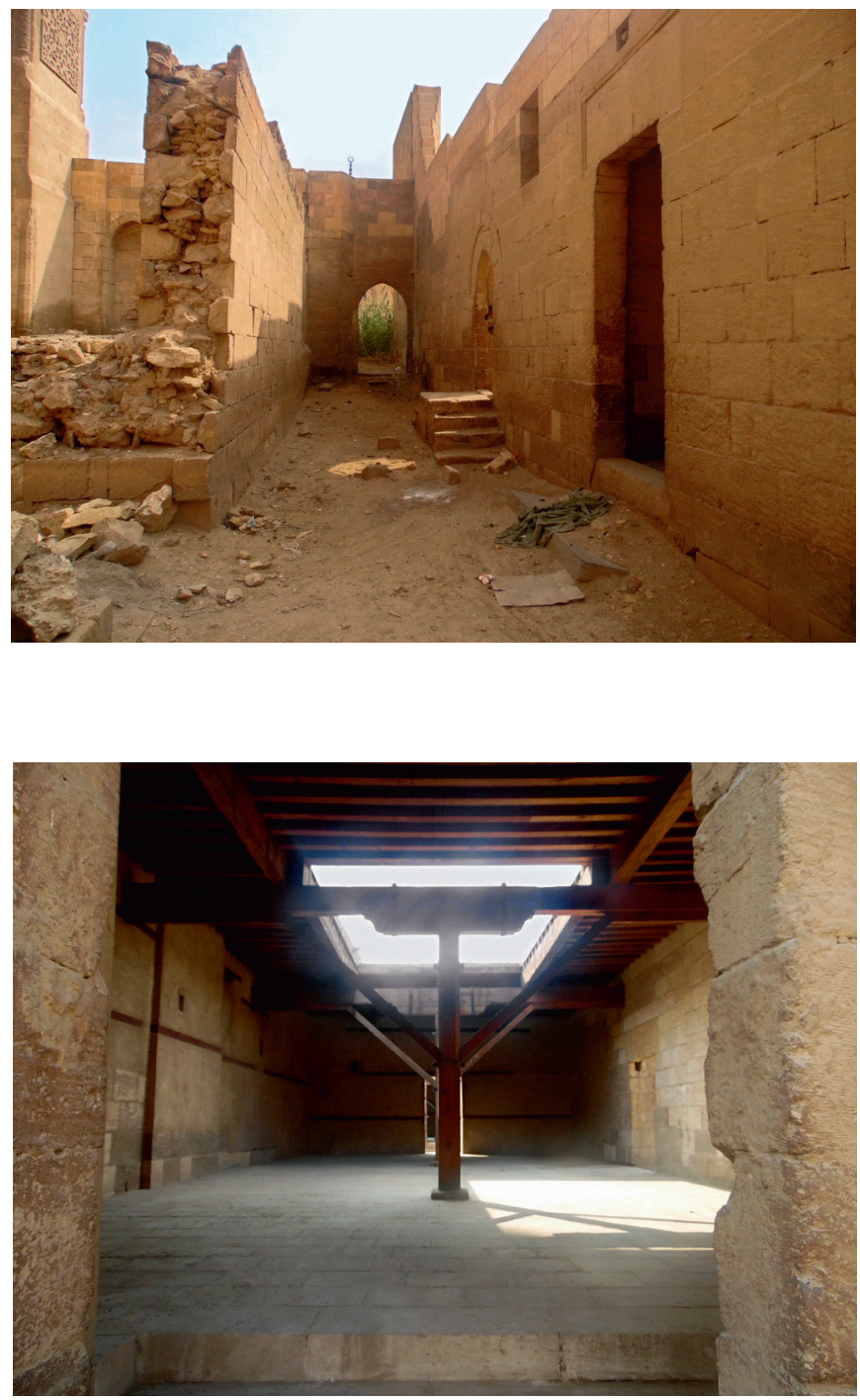

now, which means that Court C is in fact the turba of Jirbāsh Qāshiq without any doubt.

Another part of the waqfiyya of Qurqumās, describing the inner court, which lies to the east of the madrasa and the residential part (qașr) at the south of the complex of Ināl, mentions three doors. One door is blocked, the second is adjacent to the turba of Faḍil Allah, and the third is adjacent to the turba of al-Qādī 'Abd al-Bāsiț.101 With this description in mind, we can sketch the surroundings of the turba of Jirbāsh Qāshiq (Fig. 17).

\section{Who Was Jirbāsh Qāshiq?102}

Amīr Sayf al-Dīn Jirbāsh min ‘Abd al-Karīm al-Z̄āhirī was also known as Qāshiq. Like most Turkish names, it has a meaning; jirbāsh is the name of a bird, ${ }^{103}$ and $q \bar{a} s h i q^{104}$ means 'spoon' in Turkish. ${ }^{105}$ The combination may perhaps denote gluttony; in the Mamluk tradition, a personal trait was normally used as a sobriquet following the name. He was a Circassian born c. 770/1368-9, purchased and manumitted by al-Ẓāhir Barqūq during his first sultanate (784-91/1382-9).106 Sulțān Faraj b. Barqūq (r. 801-8/1398-1405 and 8०8-15/1405-12) made Jirbāsh silāḥdār. He later became amīr shara, and was eventually promoted to the highest rank in the Mamluk army, amir mäa muqaddam alf, at the
FIGURE 15

Cul-de-sac $(z u q \bar{a} q)$

FIGURE 16

Empty room intended for a flour mill

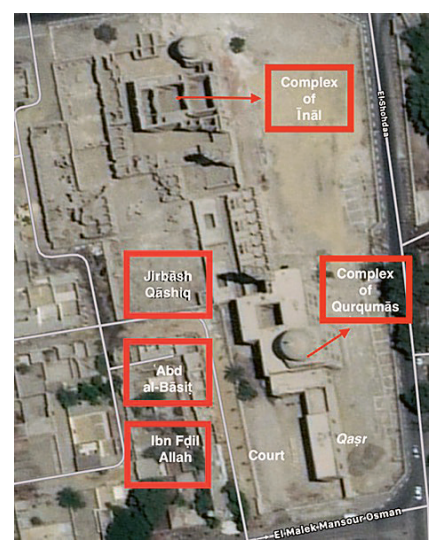

FIGURE 17

Surroundings of the turba of Jirbāsh Qāshiq 
end of the sultanate of al-Mu'yyad Shaykh (r. 815-24/1412-21).107 Jirbāsh was arrested and imprisoned in the Damascus Citadel by the Atābiq Țațar (d. 824/1421) during the short reign of al-Muzafar Ahmad b. Shaykh (r. 824/1421) for unknown reasons. ${ }^{108}$

The reign of Sulțān al-Ashraf Barsbāy (825-41/1422-37) witnessed the rise of Jirbāsh and his fall from grace again for a longer period. Barsbāy released Jirbāsh from prison in Damascus and appointed him hạjib al-ḥjjāb (Chief Chamberlain) in Sha'bān 826/1423, a position that he held till Shawwāl 829/1426. ${ }^{109}$ During this period he was appointed commander of the second expeditionary force sent by Barsbāy to invade Cyprus in Rajab 828/1425 that eventually ended in the seizure of the island and the capture of its king, Janus (r. 1398-1432) on Ramaḍān 829/1426. The island thenceforward was reduced to vassalage status, paying yearly tribute to the sultan in Cairo until the end of the Mamluk sultanate. ${ }^{110}$

Jirbāsh's career continued to progress. He became amìr majlis (Prince of the Royal Council) in Shawwāl 829/1426, then $n a \bar{i} i b$ (Viceroy) of Tripoli in Jumāda I 830/1427, then amir majlis again in Rajab 831/1428 for a short time. He was arrested and exiled to Damietta at the end of Shawwāl 831/1428. The sultan offered to appoint him $n \bar{a} i b$ of Gaza, but he declined and remained in exile till the end of the reign of Barsbāy.111 It seems that the paranoid Sulțān Barsbāy doubted his loyalty.

After a long exile in Damietta, Jirbāsh's fortunes changed when Sulțān al-Zāāhir Jaqmaq $(842-57 / 1438-53)$ ordered his release and appointed him amir majlis for the third time in Jumāda I 842/1438. Jirbāsh remained at this post for many years, during which his daughter Zaynab married the sultan and he himself went to Mecca on pilgrimage a few times. He was elevated to the high post of amìr silāh in Șafar 853/1449 after Jaqmaq died, and held this position till his retirement four years later. Jirbāsh died in Muharam 861/1456, past the age of ninety, after a long and prosperous career, and was buried in his turba in the Șaharā’.112

\section{The Stone Blazon}

The stone blazon carrying a sword, mentioned earlier, was first described and sketched by Max van Berchem, who thought it belonged to the complex of Qurqumās, which at that time was unknown to him. Van Berchem simply referred to the complex as the Anonymous Madrasa and Mausoleum (Amir Kabir); he believed its owner was a dignitary of the era of Sultān al-Ghawrī (r. 906-22/1501-16).113 Creswell also mentions the blazon as part of the complex of Qurqumās, and calls it an "armorial badge."114 Neither Van Berchem nor Creswell, writing at the beginning of the twentieth century, recognized the relation between the blazon and the office of silāhdār.

Michael Meineke concluded correctly that Court C is not part of the Innāl complex, since its monumental entrance is hidden by part of Ināl's buildings. Furthermore, he mentioned the blazon of a silāhdār, and the three aforementioned turbas of Ibn Faḍl Allah, Khalīl b. 'Abd al-Bāsiț, and Jirbāsh Qāshiq as possible owners of the enclosure. However, he eventually excluded all three of them; the first two were disqualified, because they were civil servants without ties to the military, and thus not entitled to adopt a blazon. Although the third was a military man and a silāḥdār, Meineke excluded him, based on the argument that he died in the mid-ninth/fifteenth century when simple blazons were not in use. Instead, he suggested Kūkāī al-Silāḥdār (d. 749/1349) who lived when simple blazons were the order of the day and who was buried near the complex of Īnāl, according to Ibn Taghrībirdī's narrative. ${ }^{115}$

In fact, Ibn Taghrībirdī, in his obituary of Kūkāī, states that the latter owned a turba with a minaret in the Șaḥarā in the direction of the turba of al-Malik al-Ẓāhir Barqūq. ${ }^{116}$ 
This is a very general topographical reference matching several possible choices, and in no way as precise as the account given in the waqfiyya of Qurqumāsi17 discussed earlier, defining the location of the turba of Jirbāsh Qāshiq. No less significant for the dismissal of the Kükāi attribution is the minaret mentioned by Ibn Taghrībirdī, as there is no sign of the presence of a minaret at enclosure C. Minarets are normally located next to the gate and require a deep foundation, and we have no archaeological evidence for such a structure near the entrance or in any other part of the enclosure.

Meineke assumed that the unidentified Ibn Faḍl Allah mentioned in the waqfiyya was Badr al-Dīn Muhammad b. Yahyā b. Faḍl Allah (d. 746/1345),, 118 a scion of the famous family of Faḍl Allah, and dated the turba accordingly, in spite of the fact that Badr al-Dīn died in Damascus. ${ }^{119}$ This turba must have been a collective burial place for this famous Syrian family that served the sultanate for over a century in the important position of kātib al-sir (confidential secretary) in Cairo and Damascus. ${ }^{120}$ In addition to this turba in Cairo they also had a family turba on Qāisūn hill, a suburb of Damascus. Indeed, the waqfiyya mentions a turba for Ibn Faḍl Allah, not aāl (family of) Faḍl Allah, but this could be an error on the part of the transcriber. ${ }^{121}$ Attributing the turba to a specific member of the family or giving it a precise date of erection is pure conjecture.

According to Sami Hasan, Max Herz found a blazon with a sword in the ruins of Court C between the complexes of Īnāl and Qurqumās, and moved it to the Islamic Museum, where it is preserved under number 1446/1. Like Van Berchem and Creswell, Herz attributed the blazon and the entire area to Qurqumās, believing that the sword blazon was for the atābik al-'asākir (Commander in Chief of the Mamluk army). ${ }^{122}$ Hasan argues that the blazon is indeed for an atābik, but that Innāl was the owner, since he was also an atābik before ascending to the throne. Hasan also reports seeing another identical blazon on the upper right-hand side of the portal during a field visit c. $1976,{ }^{123}$ and asserts that the enclosure is another court of burial annexed to the complex of Innāl. ${ }^{124}$ Joyce Tovell studied the complex in detail, and described Court $C$ without adding any significant information, except that the blazon was stored at the complex of Qurqumās in $1990 . .^{125}$

We cannot exclude the possibility, contrary to Meinecke, that Jirbāsh Qāshiq adopted a simple blazon with a sword, for he was a silāhlār very early in his career at the beginning of the ninth-fifteenth century, when the simple blazons could still have been common. It is well known that most of the amirs kept their early blazons throughout their entire career without changes. ${ }^{126}$ Al-Ashraf Barsbāy (r. 825-41/1422-37) still used the simple blazon of jamadār (a lozenge) on the portal of his Ashrafiyya madrasa (Index 175, 829/1425 - Fig. 18).

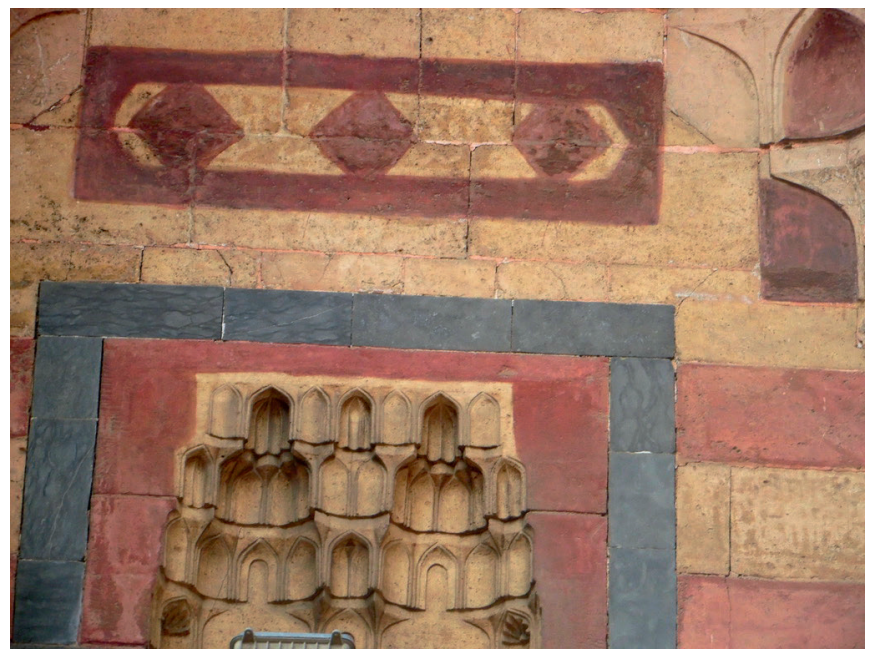

FIGURE 18 Simple blazon on the Madrasa of al-Ashraf Barsbāy 
In the absence of a waqfiyya or other literary evidence mentioning the turba, we have to infer the date range from other sources. We have already established that the turba of Jirbāsh was built before the Khanqāh of Īnāl, which was completed, according to its foundation inscription, in Muharam 858/1454. ${ }^{127}$ This gives us the terminus ad quem, or the latest possible date of construction. The terminus ante quem, or the earliest date of construction, is harder to establish, as Jirbāsh died at an advanced age after a long and prosperous career. One possibility, if we assume that the stone blazon of silāhdār and/ or amìr silăh belonged to Jirbāsh, could be the year 853/1449 when he was appointed to that post, as we have mentioned above. With our current knowledge, narrowing down that date span is not possible.

\section{Conclusion}

Șaḥarā' al-Mamālik, or the Northern Cemetery of Cairo, is dotted with thirty-six surviving Mamluk monuments, perhaps forming the largest concentration of Mamluk monuments in a contained area. The dominant building genre is the turba complex, composed of several units scattered around an open court, mostly in a walled enclosure, either large or small. The few monuments that are anonymous or of uncertain attribution require detailed multidisciplinary study; this article falls under the scope of those studies.

A modest, semi-ruined, rectangular enclosure between the two spectacular complexes of Īnāl and Qurqumās has baffled scholars since the beginning of the twentieth century. Van Berchem, in 1904, thought it belonged to the then unnamed complex of Qurqumās. Creswell, in 1919, believed the same, but named the complex. Patricolo, in 1922, hesitatingly called it Court C of the complex of Īnāl. Subsequent studies have until now not challenged Patricolo's assumption, with respect to discussions or depictions of the plan, which are too numerous to mention here. Only Meineke in 1992 questioned this assumption and suggested summarily that the enclosure belonged to amìr Kūkāî al-Silāḥdār and dates to 746/1345; however, he did not corroborate his conclusion with a deep study.

In this article I have argued that this so-called Court $\mathrm{C}$ cannot be part of any of the surrounding complexes. My proof is based on a careful reading of the part of the waqfiyya of Qurqumās that deals with the surrounding buildings, and on descriptions of details of the northern façade of the complex that I then traced on the surviving façade. We may conclude without a doubt that this court is indeed the turba of Jirbāsh Qāshiq mentioned in the waqfiyya, and that this is supported by contemporary literary evidence, and existing archaeological remains.

\section{About the Author}

Hani Hamza is an independent scholar with an MA in Islamic art and architecture from the American University in Cairo, and a PhD from the Faculty of Antiquity of Cairo University (2004). He lives in Cairo, where he researches, writes, and lectures on the history of Mamluk architecture, and other Mamluk topics. His research papers in English were published by the Mamluk Study Review (MSR) in Chicago, the AUC Press in Cairo and Brill in Leiden. He also published a monograph on the Northern Cemetery of Cairo in English, entitled The Northern Cemetery of Cairo (Mazda Publishers, 2001) and three books in Arabic on the general history of the Mamluk sultanate. 


\section{References}

\section{Primary Sources}

al-Faiyyūmī, Aḥmad b. Muhammad (1994). Al-Muṣbāḥ al-munīr. A. Elshinawi, ed., Cairo: Dār al-Māārif.

Ibn Hajar, Aḥmad b. 'Alī al-'Asqalani (n.d.). al-Durar al-kāmina fì A'yyān al-Mā't al-Thāmina. (4 vols). Beirut: Dār 'Ahīā' al-Turāth l-'Arabī.

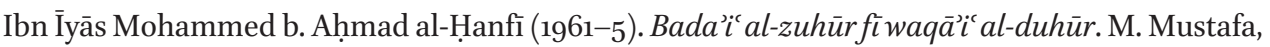
ed. (5 vols). Cairo: The Egyptian General Organization for Books.

Ibn Khalīl al-Ḥanfì, Zain al-Dīn 'Abd al-Bāsiṭ (2014). al-Raūẹ al-bāsim fì hawādith al-'umr wa l-tarājum. 'U.A. al-Tadmurī, ed. (4 vols.). Saida-Beirut: al-Maktba al-'Așriyya.

Ibn Manzūr, Jamāl al-Dīn Muhammad (1981). Lisān al-'Arab. Cairo: Dār al-Macārif.

Ibn Taghrībirdī, Abū l-Mahāsin Yūsuf. al-Nujūm al-zāhira fì mulūk Miṣr wa-l-Qāhira. F. Shaltūt, ed. (1929-56), Volumes 1-12. I.A. Țarkhān, ed. (1970), Volumes 13-15. J. al-Shayyāl and F. Shaltūt, eds. (1972), Volume 16. Cairo: The Egyptian General Organization for Books.

Ibn Taghrībirdī, Abū l-Mahāsin Yūsuf. al-Manhal al-șāfì wa-l-mustawfì ba'd al-wāfı̀. M.M. Amīn and S.A. 'Āshūr, eds. (1984-5), Volumes 1 and 2. N.M. 'Abd al-Azīz, ed. (1986), Volume 3. M.M. Amīn, ed. (1986), Volume 4. N.M. 'Abd al-Azīz, ed. (1988), Volume 5. M.M. Amīn, ed. (1990-2011), Volumes 6-13. Cairo: Dār al-Kutub wa l-Wathāq al-Mașriyya.

al-Maqrīzī, Taqī al-Dīn Aḥmad (2013). Al-Mawā'iz wa l-ítibār fì dhikr al-khițațwa l-athār (al-khiṭaț al-maqrīziyya). Ayman Fu’ād Sayyid, ed. (4 vols). London: Al-Furqān Islamic Heritage Foundation.

al-Maqrīzī, Taqī al-Dīn Aḥmad. Kitāb al-Sulūk li-márifat duwal al-mulūk. M.M. Ziyāda, ed. (195672), Volumes 1 and 2. S.A. 'Āshūr, ed. (1970-3), Volumes 3 and 4. Cairo: The National Library Press.

al-Ṣafadī, Șalāh al-Dīn Khalīl b. Aybak (1998). A'īān al-'aṣr wa' 'a'wān alnașr. N. Abū 'Amsha, M. Maūid, and M.S. Muhammad, eds. (6 vols). Damascus: Dār al-Fikr.

al-Sakhāwī, Shams al-Dīn Muhammad (1966). al-Daū', al-lāmi` fí a'yān al-qarn al-tāsic. (12 vols). Beirut: Dār al-Jīl.

\section{Secondary Sources}

Ahmed, A.A. (2006). al-Rainūk al-Islāmiyya. Cairo: Faculty of Arts, 'Aīn Shams University.

Amin, M.M., and Ibrahim, L.A. (1990). Architectural Terms in Mamluk Documents (648-923H) (1250-1517). Cairo: AUC Press.

Beherens-Abouseif, D. (1981). Four Domes of the Late Mamluk Period. Annales Islamologiques 17, pp. 191-210.

Briggs, M.S. (1922). Architecture in Egypt and Palestine. Oxford: Clarendon Press.

Comité du Conservation des Monuments de l'Art Arabe. (1892-196o). Bulletin du Comité du Conservation des Monuments de l'Art Arabe. (40 vols.). Cairo: https://www.persee.fr/ collection/ccmaa.

Creswell, K.A.C. (1919). A Brief Chronology of the Mohammadan Monuments of Egypt to A.D. 1517. Bulletin de l'Institut Français d'Archéologie Orientale 15, pp. 39-164.

Darrag, A. (1963). L'Acte de Waqf du Sulțān al-AshrafBarsbay. Cairo: Institut Français d'Archéologie Orientale.

Dobrowolski, J. (1995). A Polish-Egyptian Restoration Project at the Eastern Cemetery in Cairo. In: J.L. Bacharach, ed., The Restoration and Conservation of Islamic Monuments in Cairo, Cairo: AuC Press, pp. 76-9.

Dozy, R. (1980). Taqmalat al-ma'äjim al-'Arabiyya. Translated by M.S. al-Nu'imī. Volume 2. Baghdad: Dār al-Rashīd.

El Kadi, G., and Bonnamy, A. (2007). Architecture for the Dead: Cairo's Medieval Necropolis. Translated by P. Dresner and P. Ghazalleh. Cairo: AUC Press. 
Franz, J. (1896). Baukunst des Islam. Darmstadt: Publisher unknown.

Hamza, H. (2001). The Northern Cemetery of Cairo. Costa Mesa, CA: Mazda Publishers Inc.

Hamza, H. (2004). al-Turab al-mamlūkiyya bi-madinat al-Qahira (648-923 AH/1250-1517 AD), PhD Thesis, Faculty of Archaeology, Cairo University.

Hamza, H. (20o9). The Turba of Azdamur (al-Zumur) in the Northern Cemetery of Cairo. In: B. O'Kane, ed., Creswell Photographs Re-examined: New Perspective on Islamic Architecture, Cairo: AUC Press, pp. 135-52.

Hamza, H. (2014). Miṣr al-Mamlūkiyya: qirāa jadīda. Cairo: El Ain Publishing.

Hamza, M. (1986). Qarāfat al-Qāhira fi 'așr al-salāțin al-mamālīk, PhD Thesis, Faculty of Archaeology, Cairo University.

Hasan, S.A. (1976). al-Sulțān İnāl wa athārih al-mi'māriyya fì al-Qāhira, PhD Thesis, Faculty of Arts, Cairo University.

Herz, M. (1914). Index général du Bulletin du Comité des années 1882 à 1910. Cairo: Comité de Conservation des Monuments de l'Art Arabe.

Lane-Poole, S. (1886). Art of the Saracens in Egypt. London: Chapman and Hall, Limited. (Reprinted at Beirut: Librairie Byblos).

Lane-Poole, S. (n.d.). Cairo. In: C.W. Wilson, ed., Picturesque Palestine Sinai and Egypt, vol. 4, London: J.S. Virtue and Co., Limited, pp. 151-5.

Leisten, T. (2000). Turba. The Encyclopedia of Islam: New Edition 10, pp. 673-5.

Majma' al-lughat al-'Arabiyya (1985). al-Majam al-wasiț. (2 vols). Cairo: Majmac al-lughat al-'Arabiyya.

Mayer, L.A. (1933). Saracenic Heraldry: A Survey. Oxford: Clarendon Press.

Meineke, M. (1972). Zur mamlukischen Heraldik. Mitteilungen des Deutschen Archäologischen Instituts Abteilung Kairo 28 (2), pp. 119-48.

Misiorowsky, A. (1979). Mausoleum of Qurqumās in Cairo: An Example of the Architecture and Building Art of the Mamlouk Period. Warsaw: State Enterprise for the Conservation of Cultural Property.

Naguib, M.M. (1975). Madrasat al-amīr kabīr Qurqumas wa mulhaqātiha, dirāsa mi'māriyya athāriyya (al-mulhaq al-wathā'iqū), PhD Thesis, Faculty of Archaeology, Cairo University.

O'Kane, B. The Monumental Inscriptions of Historic Cairo. https://islamicinscriptions.cultnat.org.

Ohtoshi, T. (1993). The Manners, Customs, and Mentality of Pilgrims to the Egyptian City of the Dead 1100-1500 A.D. Orient 24, pp. 19-44.

Ohtoshi, T. (2006). Cairene Cemeteries as Public Loci in Mamluk Egypt. Mamluk Studies Review $10(1)$, pp. $83-116$.

Ormos, I. (2009). Max Herz Pasha (1850-1919): His Life and Career. (2 vols). Cairo: AUC Press.

Qāsim, H. (2018). al-Mazārāt al-Īslāmiyya wa l-athār al-'Arabiyya fì Miṣr wa l-Qāhira al-Mu iziyya. (8 vols). Alexandria: Bibliotheca Alexandrina.

Rabbat, N. (1995). Rank. The Encyclopedia of Islam: New Edition 8, pp. 431-3.

Ragib, Y. (1999). Le site du Muqattam. Annales Islamologiques 33, pp. 159-84.

Rizk, 'A.M. (2003). al-'Imāra a-Īslāmiyya bi'l Qāhira fì 'așr dawlat al-mamālīk al-burjìyya (784-923 $\left.A H,{ }_{13} 82-1517 A D\right)$. (2 vols). Cairo: Madbouli.

Sauvaget, J. (1950). Noms et surnoms des Mamlouks. Journal Asiatique 238, pp. 31-58.

Survey Department of Egypt (1951). Faihrist al-athār al-Īslāmiyya bì madinat al-Qāhira. Cairo: Survey of Egypt.

Taylor, C. (1998). In the Vicinity of the Righteous. Leiden: E.J. Brill.

Tovell, J. (1991). The Khankah of Sultān Inal in the Northern Cemetery in Cairo, MA Thesis, American University in Cairo.

Van Berchem, M. (1894). Matériaux pour un Corpus Inscriptionum Arabicarum - Égypte I. Paris: Ernest Leroux. 
Notes

Survey Department of Egypt (1951), Faihrist al-athār al-İslāmiyya bī madinat al-Q̄āhira, Cairo: Survey Department of Egypt. Referred to here as Index.

Lane-Poole S. (1886), Art of the Saracens in Egypt, London: Chapman and Hall, Limited (reprinted at Beirut: Librairie Byblos), p. 88.

Lane-Poole, S. (n.d.), Cairo. In: C.W. Wilson, ed., Picturesque Palestine Sinai and Egypt, vol. 4, London: J.S. Virtue and Co., Limited, pp. 151-5.

Briggs, M.S. (1922), Architecture in Egypt and Palestine, Oxford: Clarendon Press, p. 122.

Creswell, K.A.C. (1919), A Brief Chronology of the Mohammadan Monuments of Egypt to A.D. 1517, Bulletin de l'Institut Français d'Archéologie Orientale 15, pp. 134, 155.

Naguib, M.M. (1975), Madrasat al-amìr kabìr Qurqumas wa mulhaqātiha, dirāsa mi'māriyya athāriyya (al-mulhaq al-wathāiqū), PhD Thesis, Faculty of Archaeology, Cairo University.

Hasan, S.A. (1976), al-Sulțān İnāl wa athārih al-mímāriyya fì l-Qāhira, PhD Thesis, Faculty of Arts, Cairo University.

Tovell, J. (1991), The Khankah of Sulțān Inal in the Northern Cemetery in Cairo, MA Thesis, American University in Cairo.

Taylor, C. (1998), In the Vicinity of the Righteous, Leiden: E.J. Brill.

Ohtoshi, T. (1993), The Manners, Customs, and Mentality of Pilgrims to the Egyptian City of the Dead 1100-1500 A.D., Orient 24, pp. 19-44.

Ohtoshi, T. (2006), Cairene Cemeteries as Public Loci in Mamluk Egypt, Mamluk Studies Review $10(1)$, pp. 83-4.

Al-Faiyyūmi, Aḥmad b. Muhammad (1994), Al-Muṣbāḥ al-munīr, A. Elshinawi, ed., Cairo: Dār al-Ma`ārif, p. 73; Majma' al-lughat al-'Arabiyya, (1985), Al-Majam al-wasīt (2 vols), Cairo: Majmac al-lughat al-'Arabiyya, p. 1: 86; Leisten, T. (2000). Turba, The Encyclopedia of Islam: New Edition 10, pp. 674 .

Ibn Manzūr, Jamāl al-Dīn Muhammad (1981), Lisān al-'Arab, Cairo: Dar al-Macārif, p. 423. Ibid., p. 1728.

Majama' al-Lughat, al-Majam al-wasiț, p. 1: 86; Leisten, Turba, p. 674.

Amin, M.M., and Ibrahim, L.A. (1990), Architectural Terms in Mamluk Documents (648-923H) (12501517), Cairo: AUC Press, pp. 85.

Dozy, R. (1980), Taqmalat al-ma'ājim al-'Arabiyya, translated by M.S. al-Nu'imī, volume 2. Baghdad: Dār al-Rashīd, p. 27.

8 Amin and Ibrahim, Architectural Terms, p. 85; Leisten.,Turba, p. 674; Hamza, M. (1986), Qarāfat al-Qāhira fì 'așr al-salāțīn al-mamālīk, PhD Thesis, Faculty of Archaeology, Cairo University, p. 164; El Kadi, G., and Bonnamy, A. (2007), Architecture for the Dead: Cairo's Medieval Necropolis, translated by P. Dresner and P. Ghazalleh, Cairo: Auc Press, pp. 224, 252.

9 The other cemeteries of Medieval Cairo, according to al-Maqrīzī, are the greater qarafa to the east of Fusțât, the lesser qarafa at the foot of the Muqațtam hill, the Fatimid caliph's cemetery inside Cairo known as Turbat al-Za'farān, the one outside Bāb Zūayla between the Mosque of al-Ṣāih Ṭalā’` $i^{`}$ and the Citadel, the one outside Bāb al-Nașr in Ḥusaynyya, and the one between Bāb al-Futūḥ and alKhandaq. See: al-Maqrīzī, Taqī al-Dīn Aḥmad, Kitāb al-Sulūk li-márifat duwal al-mulūk, M.M. Ziyāda, ed. (1956-72), Volumes 1 and 2.; S.A. 'Āshūr, ed. (1970-3), Volumes 3 and 4, Cairo: The National Library Press, pp. 2: $442-3$.

Hamza, H. (2001), The Northern Cemetery of Cairo, Costa Mesa, Ca.: Mazda Publishing Inc., pp. 54-5. The original name of the area was Maydān al-Qabaq (after a Mamluk military game that was practiced there). Later it was called al-Maydān al-Asūwad (black), al-Mayḍān al-Akhdar (green), Maydān al-Sibāq (race), and Maydān al-'̄̄d. Modern names include Maqābir al-Khulafā' (though no caliph is buried there), cemetery of al-Majawirinn, cemetery of Qāìtbay, and the Eastern Cemetery. The area is now often referred to in literature as the Northern Cemetery of Cairo. See: Ibid., p. 19.

Ibid., 2.

Ibid., 4-5.

He was a senior amīr of al-Manșūr Qalāwūn and his successors, and played a major role in the military and political strife at the end of the seventh/thirteenth and the beginning of the eighth/fourteenth centuries. He became nā̉ib (viceroy) of Hama and Damascus. Qarāsunqur fell out with al-Nāṣir Muhammad, but managed to escape his wrath by defecting to the Mongols in 712/1312. The Mongol IlKhan Muhammad Khodhabanda (Oljeitu) (r. 704-16/1304-16) received him well and appointed him Viceroy of Maragha (now in Iran), where he died in his bed in 728/1328, in spite of the many attempts on his life by the vengeful sultan al-Nāșir Muhammad. For his biography see: al-Șafadī, Șalāḥ al-Dīn Khalīl b. Aybak, (1998), A'īān al-'așr wa' 'a'wān alnașr, N. Abū 'Amsha, M. Maūiid, and M.S. Muhammad eds. (6 vols), Damascus: Dār al-Fikr, pp. 4: 87-100; Ibn Hajar, Ahmad b. 'Alī (n.d.), 
al-Durar al-kāmina fì A'yyān al-Mā̀t al-Thāmina (4 vols), Beirut: Dār 'Ahị̄ā' ai-Turāth l-'Arabī, pp. 3: 2467; Ibn Taghrībīrdī, Abū l-Mahāsin Yūsuf, al-Manhal al-șāfì wa-l-mustawfí ba'd al-wāfì, M.M. Amīn and S.A. 'Āshūr, eds. (1984-5), Volumes 1 and 2; N.M. 'Abd al-Azīz, ed. (1986), Volume 3; M.M. Amīn, ed. (1986), Volume 4; N.M. 'Abd al-Azīz, ed. (1988), Volume 5; M.M. Amīn, ed. (1990-2011), Volumes 6-13, Cairo: Dār al-Kutub wa l-Wathā'q al-Mașriyya, pp. 9:47-8.

Others may also have built there at more or less the same time, but the sources are contradictory as to who was the first to build. The consensus, however, is that building mausoleums at the Șaharä started around this date. Hamza, The Northern Cemetery, p. 5.

Al-Ashraf Barsbāy (Index 121, 835/1432), al-Ashraf Īnāl (Index 158, 855-6o/1451-6), al-Ashraf Qaytbāī (Index 223, 880/1475), and al-Ashraf Qansūa Abū Sa'īd (Index 102, 904/1499).

27 The discussion about the area in this article is limited to the Mamluk era. For a description of the area and the history before the Mamluks, see: Ragib, Y. (1999), Le site du Muqattam, Annales Islamologiques 33, pp. 159-84. For a discussion of the area up to the modern time, see: El Kadi and Bonnamy, Architecture for the Dead, pp. 171-252.

For a description and photographs see: Qāsim, H. (2018), al-Mazārāt al-İslāmiyya wa l-athār al-'Arabiyya fì Mișrwa l-Qāhira al-Mu izizyya. (8 vols), Alexandria: Bibliotheca Alexandrina, pp. 4: 3756; Behrens-Abouseif, D. (1981), Four Domes of the Late Mamluk Period, Annales Islamologiques 17, p. 199, plates XIV, C-D; Rizk, 'A.M. (2003), al-Imāra a-Īslāmiyya bi'l Qāhira fí 'așr dawlat al-mamālìk al-burjiyya (784-923 AH, 1382-1517 AD) (2 vols), Cairo: Madbouli pp. 2: 1994-200o.

O'Kane, B., The Monumental Inscriptions of Historic Cairo, https://islamicinscriptions.cultnat.org Inscrip. No. 108.1, 108.3.

30 Qāsim, al-Mazārāt al-İslāmiyya, p. 4: 375; Behrens-Abouseif, Four Domes, p. 199. For the related stipulations in the waqfiyya, see: Darrag, A. (1963), L’Acte de Waqf du Sulțān al-Ashraf Barsbay, Cairo: Institut Français d'Archéologie Orientale, pp. 46-7.

31 Qāsim, al-Mazārāt al-Īslāmiyya, p. 4: 375.

32 Beherens-Abouseif, Four Domes, p. 199.

33 Herz, M. (1914), Index général du Bulletin du Comité des années 1882 à 1910, Cairo: Comité de Conservation des Monuments de l'Art Arabe, p. Xxxviır.

34 Creswell, Brief Chronology, pp. 132-3.

35 Qāsim, al-Mazārāt al-Īslāmìyya, p. 4:389.

36 Hamza, The Northern Cemetery, p. 16.

37 Qajmās was an avid builder and he founded more than one turba: one in Cairo at the Northern Cemetery, mentioned above; one in Alexandria outside Bāb Rashīd (Rosetta), where Sulțān al-Ẓāhir Tamirbūgha (r. for two months in 872/1468) was buried; and one in Alexandria, where he himself was buried. See: al-Sakhāwī, Shams al-Dīn Muhammad (1966), al-Dạù', al-lāmi`fì a'yān al-qarn al-tāsic (12 vols), Beirut: Dār al-Jīl, pp. 6: 213-4.

The other dome is that of the madrasa of Taghrī Birdī at Șalība Street (Index 209, 844/1440). See: Creswell, Brief Chronology, pp. 126-7.

41 Qāsim, al-Mazārāt al-İslāmiyya, 4: 376-7.

42 Hamza, The Northern Cemetery, 14, 15.

43 Herz, Index général du Bulletin du Comité, p. xxxviı.

44 Creswell, Brief Chronology, p. 157.

45 Qāsim, al-Mazārāt al-Īslāmìya, p. 4:365.

46 For a detailed description of the monument see: Hamza, H. (2004), al-Turab al-mamlūkiyya bi-madinat al-Qahira (648-923 AH/1250-1517 AD), PhD Thesis, Faculty of Archaeology, Cairo University, pp. 178-84.

Herz, Index général du Bulletin du Comité, pp. xxxviı.

Hamza, al-Turab al-mamlūkiyya, p. 177.

Ibid.

Qāsim, al-Mazārāt al-Īslāmiyya, pp. 4: 346-7.

Hamza, The Northern Cemetery, p. 24.

Hamza, H. (2009), The Turba of Azdamur (al-Zumur) in the Northern Cemetery of Cairo. In: B.O'Kane, ed., Creswell Photographs Re-examined: New Perspective on Islamic Architecture, Cairo: AUC Press, pp. 136-42.

Ibid., p. 135 .

Qāsim, al-Mazārāt al-Īslāmiyya, pp. 4: 39o.

Hamza, The Turba of Azdamur, pp. 135-52.

The Egyptian side was the Egyptian Antiquities Organization; the Polish participants were PKz, a state-owned company for monument restoration, and the Polish Archaeological Center of Warsaw University. 
57 Dobrowolski, J. (1995), A Polish-Egyptian Restoration Project at the Eastern Cemetery in Cairo. In: J.L. Bacharach, ed., The Restoration and Conservation of Islamic Monuments in Cairo, Cairo: AUC Press, pp. $76-9$.

58 Misiorowsky, A. (1979), Mausoleum of Qurqumās in Cairo:An Example of the Architecture and Building Art of the Mamlouk Period, Warsaw: State Enterprise for the Conservation of Cultural Property, pp. 8-9.

59 Ibid., pp. 57-63.

6o Ibid., p. 19 .

61 Comité du Conservation des Monuments de l'Art Arabe (1892), Fascicule 1, exercice 1882-3, p. 65.

62 Comité (1906), Fascicule 10, exercice 1893, p. 54.

63 Comité (1896), Fascicule 11, exercice 1894, pp. 112-3.

64 Comité (1896), Fascicule 12, exercice 1895, pp. 20-1.

65 Ibid., pp. $32-3$.

66 Ibid., pp. 94-5.

67 Comité (1898), Fascicule 14, exercice 1897, p. 38.

68 Comité (1900), Fascicule 17, exercice 1900, pp. 6-7.

69 Comité (1903), Fascicule 20, exercice 1903, p. 24.

$70 \quad$ Comité (1904), Fascicule 21, exercice 1904, p. 35.

71 Comité (1909), Fascicule 25, exercice 1908, pp. 65-6.

72 Comité (1916), Fascicule 31, exercice 1914, p. 104.

73 Comité (1922), Fascicule 32, exercice 1915-9, pp. 144-8.

74 Achille Patricolo (d. 1937) was a Sicilian architect in the service of the Comité in 1906. He succeeded Max Herz (d. 1919) as head of the technical committee of the Comité till he retired suddenly in 1922. See: Ormos, I. (2009), Max Herz Pasha (1850-1919): His Life and Career (2 vols), Cairo: AUC Press, p. $1: 28$.

75 Franz, J. (1896), Baukunst des Islam, Darmstadt: Unknown publisher, p. 104.

76 Comité (1922), Fascicule 32, exercice 1915-9, p. 147.

77 For example, the nearby contemporary turba of Barsbay al-Bajāsi (Index 124, c. 86o/1456, Fig. 11, which has a similar plan, but its surviving foundation inscription provides a definite date of construction and attribution. See: O'Kane, The Monumental Inscriptions, Inscrip. 14.9, 14.17. It also resembles the lost turba of Abū l-Mahāāin b. Taghrībirdī reconstructed from the reading of his waqfiyya (Fig. 12).

78 The waqfiyya calls its eastern border sharqī, which is actually true north. I observed that in the terminology of waqfiyya writers at the Northern Cemetery of Cairo, 'south,' qibli, is used for true east, which is approximately the qibla direction in Cairo. Consequently, 'south' for waqfiyya writers means true west, 'east' means true north, and 'west' means true south, allowing for minor deviation.

79 I use the text of the waqfiyya of Qurqumas published at al-mulhaq al-wathä'iqü. See: Naguib, Madrasat al-amìr kabìr (al-mulhaq al-wathä’iqū), p. 26, lines 13-5; p. 27, lines 1-5.

8o Patricolo, in his report to the Comité, made the same observation. See: Comité (1922), Fascicule 32, exercice 1915-9, p. 147.

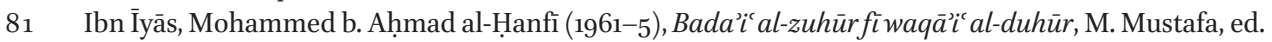
( 5 vols), Cairo: The Egyptian General Organization for Books, p. 2: 331.

82 Faḍl Allah is the name of a family of civil servants who served the Mamluk administration for almost a century, from the end of the seventh/thirteenth century to the end of the eighth/fourteenth century. They were mostly buried in Damascus. The waqfiyya doesn't mention a precise name, which leads us to believe that it was a collective turba for the family in spite of the use of the term $i b n$, meaning 'son,' rather than banū, meaning 'progeny.' See: Naguib, Madrasat al-amīr kabìr (al-mulhaq al-wathäiqū), pp. 139-43.

83 For his biography see: Ibn Taghrībirdī, Manhal, pp. 7: 136-43; al-Sakhāwī. Daū’, pp. 4: 24-7; Ibn İyās, Badā'i, pp. 2: 285-6.

84 Comité (1922), Fascicule 32, exercice 1915-9, pp. 171-2.

85 Kūkāī was a senior amìr of al-Nāṣir Muhammad, an amìr mä̉a muqaddam alf, the highest military rank in the Mamluk army. He was known for his valor and extreme wealth; at his death, he left a fortune of more than forty thousand dinar in addition to horses, clothes, tents, houses, and other properties. He died in Jumāda I 749/1349, and was buried in the Șaharā’ in a tomb with a minaret that he built for himself. For his biography see: al-Ṣafadī, A'īān al-'așr, pp. 4: 163-4; Ibn Hajar, Durar, p. 3: 270; al-Maqrīzī, Sulūk, p. 2: 796; Ibn Taghrībirdī, Abū l-Mahāsin Yūsuf, al-Nujūm al-zāhira fì mulūk Miṣr wa-l-Qāhira, F. Shaltūt, ed. (1929-56), Volumes 1-12; I.A. Ṭarkhān, ed. (1970), Volumes 13-15; J. al-Shayyāl and F. Shaltūt, eds. (1972), Volume 16, Cairo: The Egyptian General Organization for Books, p. 10: 241.

86 Meineke., M. (1972), Zur mamlukischen Heraldik, Mitteilungen des Deutschen Archäologischen Instituts Abteilung Kairo 28 (2), pp. 244-5. 
87 Waqfiyya of Innāl, p. 2 line 2. This manuscript at the Ministry of Waqf (Ms 91oq dated 17 Dhū l-Hijja 861/o5 November 1456) is now lost; therefore, I refer here to its text published by Sami Ahmad Hasan. See: Hamza, al-Turab al-mamlūkiyya, p. 110.

"Al-Sayfi" is a title that precedes the name of ahl al-sayf (people of the sword), meaning soldiers. Al-Karīmī refers to Abd al-Karīm, most probably the slave merchant who brought him from his country of origin and sold him in Egypt, in accordance with the Mamluk naming tradition.

89 Ministry of Waqf Ms 9o1. I use here the text published by Mustafa Naguib. See: Naguib, Madrasat al-amìr kabìr (al-mulhaq al-wathä'iqū), pp. 14-54.

$90 \quad$ Ibid., p. 26.

91 This part is translated into French by Patricolo. See: Comité (1922), Fascicule 32, exercice 1915-9, pp. 171. There is also an English translation of the waqfiyya by the Polish-Egyptian Group published in: Misiorowsky, Mausoleum of Qurqumās in Cairo, pp. 57-6o. (') denotes the end of a line in the waqfiyya manuscript. Amin and Ibrahim, Architectural Terms, p. 22. of a balustrade for decoration. See: Ibid., 56 .

A term used in the waqfiyyas to refer to a building under construction or that is not complete. See: Ibid., p. 110.

According to Mustafa Naguib, the flourmill was planned, but never constructed. Naguib, Madrasat al-amìr kabīr (al-mulhaq al-wathä’iqū), pp. 56-57. Amin and Ibrahim, Architectural Terms, 99.

98 Ibid., p. 57.

99 Naguib, Madrasat al-amìr kabīr (al-mulhaq al-wathā̉iqū), pp. 26-7. Mentioned in an earlier part of the waqfiyya. See: Ibid., 18.

Ibid., p. 25 .

For a biography of Jirbāsh see: Ibn Taghrībirdī, Manhal, pp. 4: 256-6o; Nujūm, pp. 16: 183-4; Ibn İyās, Badā'ic, p. 2: 377; Sakhāwī, Daü', pp. 3: 66-7.

103 Ibn Khalīl al-Ḥanfī, Zain al-Dīn 'Abd al-Bāsiṭ (2014), al-Raūẹ al-bāsim fì hawāadith al-umr wa l-tarājum, 'U.A. al-Tadmurī, ed. (4 vols), Saida-Beirut: al-Maktba al-'Așriyya, 4: 272.

104 Ibn Taghrībīrdī and ibn İyās call him Qāshiq, while al-Sakhāwi calls him 'Āshiq. I will use the former name as the first two authors were fluent in Turkish.

105 Sauvaget, J. (1950), Noms et surnoms des Mamlouks, Journal Asiatique 238, p. 51.

106 Ibn Taghrībirdī, Manhal, pp. 4: 256-7.

107 Ibid., p. 257; Ibn Taghrībirdī, Nujūm, p. 16: 183.

108 Ibn İyās, Badā'ić, p. 2: 68.

109 Ibn Taghrïbirdī, Manhal, p. 4: 257.

110 Ibn Īyās, Badā̉ic, pp. 2: 98, 100; Hamza (2014), Mișr al-mamlūkiyya: qirāa jadīda, Cairo: El Ain Publishing, pp. $145^{-52}$.

111 Ibn Taghrībirdī, Manhal, pp. 4: 258-9; Nujūm, pp. 16: 183-4; Ibn İyās, Badā’’', pp. 2: 109, 113, 119, 120.

112 Ibn Taghrībirdī, Manhal, pp. 4: 259-69; Nujūm, p. 16: 184; Ibn İyās, Badä’’', pp. 2: 200, 204, 214, 223, 277,337 .

113 Van Berchem, M. (1894), Matériaux pour un Corpus Inscriptionum Arabicarum - Égypte I, Paris: Ernest Leroux, p. 594 no. 404.

114 Creswell, Brief Chronology, p. 155 .

115 Meineke, Zur mamlukischen Heraldik, p. 244.

116 Ibn Taghrībirdī, Nujūm, p. 10: 241.

117 Naguib, Madrasat al-amìr kabìr (al-mulhaq al-wathä’iqū), pp. 26-7.

118 Meineke, Zur mamlukischen Heraldik, p. 244.

119 Ibn Taghrībirdī, Nujūm, p. 10: 143.

120 Recounting the story of the family of Faḍl Allah in detail is beyond the scope of this article, but a glance on its most prominent members will suffice. The first of the family to be appointed kātib al-sir was Sharaf al-Dīn 'Abd al-Wahāb b. Fạ̣l Allah (d. 717/1317). He was succeeded by his brother, Muhī al-Dīn Yahyyā b. Fạ̣l Allah who died at an advanced age in 738/1338. He was succeeded by three of his sons interchangeably - 'Alā' al-Dīn 'Alī b. Fạ̣l Allah (d. 769/1368), Shihāb al-Dīn Aḥmad b. Faḍl Allah, the famous scholar (d. 749/1349), and Badr al-Din Muhamad b. Faḍl Allah (d. 746/1345), nominated randomly by Meineke. The last family member to hold the job was a third-generation member called Badr al-Dīn Muhamad b. 'Alī b. Faḍl Allah (d. 796/1394). Some of them were buried initially in their turba in Cairo, but most of them were buried in Damascus. For an account of the family, and an exhaustive reference list of their obituaries see: al-Maqrīīì Taqī al-Dīn Aḥmad (2013), Al-Mawāiz wa l-ítibār fi dhikr al-khițaț wa l-athār (al-khițaṭ al-maqrizizyya), Ayman Fu'ād Sayyid, ed. (4 vols), London: Al-Furqān Islamic Heritage Foundation, pp. 3: 185-92; Naguib, Madrasat al-amīr kabīr (al-mulhaq al-wathā'iqū), pp. 139-46. 
121 Ibid., p. 139.

122 Hasan, al-Sulțān İnāl, p. 113 .

123 I did not find any trace of the blazon, neither among the existing remains of the portal during a field visit at the end of 2019, nor at the Islamic Museum in Cairo.

124 Ibid., pp. 112-4.

125 Tovell, The Khanqah of Sultān Inal, pp. 73-4, 104.

126 For discussions about blazons from the Mamluk era see: Mayer, L.A. (1933), Saracenic Heraldry: A Survey, Oxford: Clarendon Press; Meineke, Zur mamlukischen Heraldik, pp. 119-48; Rabbat, N. (1995), Rank, Encyclopedia of Islam: New Edition 8, pp. 431-3; Ahmed, A.A. (2006), al-Rainūk al-Islāmiyya, Cairo: Faculty of Arts, 'Aīn Shams University.

127 Hasan, al-Sulțān Īnāl, p. 1o8; O'Kane, The Monumental Inscriptions, Inscrip. No. 158.17. 